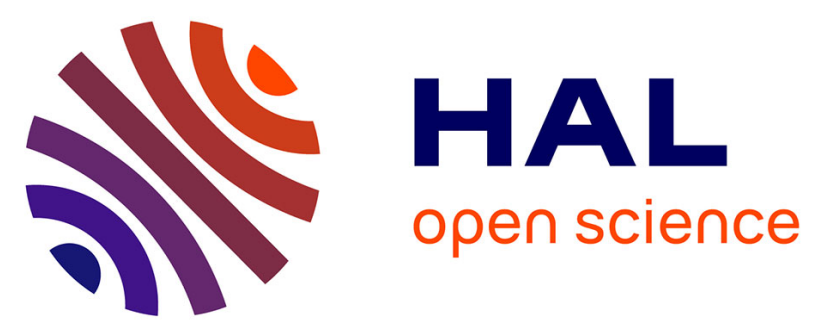

\title{
Aerosol variability induced by atmospheric dynamics in a coastal area of Senegal, North-Western Africa
} Suzanne Crumeyrolle, Patrick Augustin, Laura-Hélèna Rivellini, M. Choël, Véronique Riffault, Karine Deboudt, Marc Fourmentin, Elsa Dieudonné, Hervé Delbarre, Yevgeny Derimian, et al.

\section{To cite this version:}

Suzanne Crumeyrolle, Patrick Augustin, Laura-Hélèna Rivellini, M. Choël, Véronique Riffault, et al.. Aerosol variability induced by atmospheric dynamics in a coastal area of Senegal, North-Western Africa. Atmospheric Environment, 2019, 203, pp.228-241. 10.1016/j.atmosenv.2019.01.041 . hal02080486

\section{HAL Id: hal-02080486 \\ https://hal.science/hal-02080486}

Submitted on 22 Oct 2021

HAL is a multi-disciplinary open access archive for the deposit and dissemination of scientific research documents, whether they are published or not. The documents may come from teaching and research institutions in France or abroad, or from public or private research centers.
L'archive ouverte pluridisciplinaire HAL, est destinée au dépôt et à la diffusion de documents scientifiques de niveau recherche, publiés ou non, émanant des établissements d'enseignement et de recherche français ou étrangers, des laboratoires publics ou privés.

\section{(ㅇ)(1) $\$$}

Distributed under a Creative Commons Attribution - NonCommerciall 4.0 International 


\section{Aerosol variability induced by atmospheric dynamics in a coastal area of Senegal,} North-Western Africa

Suzanne Crumeyrolle ${ }^{1, *}$, Patrick Augustin ${ }^{2}$, Laura-Hélèna Rivellini ${ }^{1,3}$, Marie Choël ${ }^{4}$, Véronique Riffault ${ }^{3}$, Karine Deboudt ${ }^{2}$, Marc Fourmentin $^{2}$, Elsa Dieudonné ${ }^{2}$, Hervé Delbarre ${ }^{2}$,

${ }^{1}$ Univ. Lille, CNRS, UMR 8518 - LOA - Laboratoire d'Optique Atmosphérique, 59000 Lille, France

${ }^{2}$ Univ. Littoral Côte d'Opale, EA 4493 - LPCA - Laboratoire de Physico-Chimie de 10 l'Atmosphère, 59140 Dunkerque, France

${ }^{3}$ IMT Lille Douai, Univ. Lille, SAGE - Département Sciences de l'Atmosphère et Génie de l'Environnement, 59000 Lille, France

${ }^{4}$ Univ. Lille, CNRS, UMR 8516 - LASIR - Laboratoire de Spectrochimie Infrarouge et Raman, F-59000 Lille, France

15

Corresponding author: Suzanne Crumeyrolle (Suzanne.crumeyrolle@univ-lille.fr) 


\section{Abstract :}

During the first Intensive Observation Period (IOP1) of the SHADOW (SaHAran Dust Over West Africa) campaign carried out during March-June 2015, the Mbour site (Senegal) was reinforced with a large setup of in-situ and remote sensing instruments to measure the aerosol optical, physical and chemical properties as well as the atmospheric dynamical features over the site. Here, we use this dataset to study the impact of Sea Breeze (SB) on the aerosol properties.

Two case studies were selected: (i) one representative of SB events observed during typical Harmattan conditions, (ii) and one representative of SB events observed during a Harmattan desert dust event. Both cases show a strong influence of the SB period on the dry Mass Scattering Efficiency (MSE), which increases by a factor of up to 1.4. Given the fact that SB occurred every other day at this coastal site during IOP1 (dry season) and that the relative humidity may reach $96 \%$, the effect of such event on the radiative forcing may not be negligible.

In order to evaluate the effects of different flows on aerosol transport, recirculation and stagnation factors were retrieved from wind components. The air mass recirculation factor implies that aerosols previously transported from the land over the sea are then brought back inland. In both cases, high recirculation factors were calculated (between 0.84 and 0.98 ) and air mass stagnation was observed right before the SB establishment. However, this stagnation is observed over the sea during the first case while it is located near the coast during the second case, which has a significant impact on the aerosol evolution. Indeed, a stagnation of air masses over the sea is associated with an increase in fine aerosol mass concentrations $\left(\mathrm{PM}_{1}, \mathrm{PM}_{2.5}\right)$ due to a higher contribution of marine and anthropogenic sources notably for organic aerosols, and a higher contribution of more-oxidized organics. This contribution is lower when the air mass stagnation occurs over the shoreline during the desert dust event. 


\section{Introduction}

Atmospheric aerosols have significant impacts on global climate and ecosystems

5 depending on their physical and chemical properties. Aerosols originate either from natural sources or emissions by anthropogenic activities (e.g. desert dust, sea salt, black carbon, sulfate, biomass burning smoke, biogenic aerosols). On a global scale, the African continent is by far the largest source of both mineral dust and biomass burning aerosols (Bond et al., 2004; Huneeus et al., 2011). Despite advances in remote sensing measurements (Christopher et al., 2008; Winker et al., 2007), challenges remain with regard to describing precisely the vertical extension and exchanges of particles within the atmosphere and the evolution of their properties (optical, physical and chemical) during their transport. This is particularly the case over regions such as West Africa, where the presence of strong dynamic features (monsoon flux, Harmattan, Low Level Jet, etc.) are expected to cause strong diurnal, seasonal and 15 spatial variations of the aerosol microphysical properties (size distribution, shape, composition, hygroscopicity) through their transport, mixing, ageing, sedimentation, and cloud processing.

Mesoscale meteorological phenomena, such as Sea Breeze (SB) or Nocturnal Low Level Jet (LLJ), can affect moisture, heat and momentum fluxes and polluted air masses dispersion (Banta et al., 1998; Kolev et al., 1998; Luhar et al., 1998; Melas and Kambezidis, 1992; Physick and Abbs, 1992; Taubman et al., 2004). They have a significant influence on coastal air quality through their ability to efficiently mix different types of aerosols and condensable gases. This mixing could result in large modification of physical, chemical, optical and hygroscopic properties of the aerosol population (Fernández-Camacho et al., 2010; Lee et al., 2008; Piazzola et al., 2012). The processes leading to these modifications (condensation of gases, formation of secondary products/heterogeneous chemistry or the coagulation of aerosols) are dependent on the environmental conditions and especially the relative humidity (Matsuki et al., 2010). Thus, the atmospheric residence time and the radiative effects of aerosols are expected to be modified (Andreae and Crutzen, 1997).

Many studies have already been devoted to understand the SB structure (Atkins et al., 1995; Augustin et al., 2006; Nielsen, 1992; Simpson, 1969; Talbot et al., 1986) or LLJ systems (Ge et al., 2016; Hidalgo et al., 2015; Marengo et al., 2004; Pichugina et al., 2017) 
but only a few have addressed their relationship with trace gases (Brown et al., 2007; Darby, 2005; Sullivan et al., 2017). The impact of SB or LLJ phenomena, as well as their interactions, on aerosol variability is also currently poorly understood (Babu et al., 2016; Delgado et al., 2015; Moorthy et al., 1993; Pérez et al., 2016; Verma et al., 2016). Derimian et al. (2017) showed that the aerosol population over regions away from the shore (Negev desert) could be influenced by SB events. Indeed, they observed that the aerosol optical thickness, as well as the proportion of hygroscopic aerosols, increased during a SB event. Recently, few studies show that SB events are associated with an increase of $\mathrm{PM}_{1}$ and $\mathrm{PM}_{2.5}$ concentrations (Babu et al., 2016; Crawford et al., 2017; Piazzola et al., 2012; Rodríguez et al., 2008) most probably due to the production of new ultrafine particle formation events, that seem to take place over the sea, being transported back to the coast.

Mbour (Senegal) lies on the west African coast, approximately eighty kilometers south of Dakar and is often overflown by air masses originating from the Sahara and Sahel regions, which may be enriched in desert dust transported within the Harmattan (Kaly et al., 2015; Mortier et al., 2016), that move westward off the African continent (Karyampudi et al., 1999; Madougou et al., 2012). According to previous studies (Bovchaliuk et al., 2016; Léon et al., 2009; Marticorena et al., 2010; Veselovskii et al., 2018), this site is regularly influenced by a diurnal SB and nocturnal LLJ mechanism, but its influence on the aerosol variability has not yet been studied. The interaction between these dynamical features implies a high variability of the aerosol mixing state over this region of Senegal.

During the SHADOW (SaHAran Dust Over West Africa, Veselovskii et al., 2016) campaign, different atmospheric dynamical features (breeze, LLJ and trades) highlight the complexity of the dynamical circulation due to their interactions. The combination of Doppler lidar and ultrasonic anemometer shows evident interactions between SB, LLJ and Harmattan flows. Figure 1 represents a conceptual model of flow patterns in the coastal region of Senegal, which has been deduced from Doppler lidar scanning measurements during Harmattan event day. Before SB occurrence, the Harmattan advects warm, dry and dusty air masses from E/ENE to $\mathrm{W}$ directions, i.e. toward the sea (Figure 1 a). These air masses are brought back over land within the SB Gravity Current (GC) that develops during the middle of the day (Figure 1 b). Late in the afternoon, the Northerly LLJ occurs above $200 \mathrm{~m}$ and cross the SB separating the SB GC into two layers (Figure $1 \mathrm{c}$ ). The GC upper layer, becomes a residual GC layer and vanishes rapidly, reducing the GC top from about $1200 \mathrm{~m}$ down to 200-300 m. During this time lapse, called here LLJ effect period, the air mass near the ground 
may correspond mainly to a mixing of the prevailing GC and the LLJ air masses, located just above it, probably due to the Northerly LLJ wind shear effect (Figure $1 \mathrm{~d}$ ). Near the ground, interactions of these different flows may mix different types of aerosols and thus modify their physical, chemical and optical properties.

Hence, the goal of this study is to better understand the role of atmospheric dynamics on the evolution of the aerosol properties during typical SB during Harmattan events and combined SB and LLJ interaction periods over a coastal tropical region. In particular we focused our investigations on two typical SB events observed during the first Intensive Observation Period (IOP1) of the SHADOW campaign (SaHAran Dust Over West Africa, Veselovskii et al., 2016) for which in-situ measurements were used with remote sensing observations to better understand the impact of the SB and LLJ on aerosol variability. Both case studies correspond to Harmattan conditions (continental winds), but the first case occurred in the absence of dust advection, while the second one occurred during a dust event. Section 2 will introduce the campaign site and experimental setup; results and discussions about the two selected cases will be presented in section 3 while section 4 will summarize and conclude the paper.

\section{Experiment and instrumentation}

\subsection{Campaign and site description}

The SHADOW campaign took place for its first phase during the end of the dry season and the pre-monsoon period (from March to June 2015) at an observation site located at the

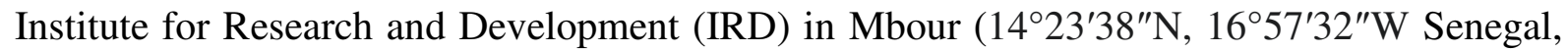
North Western Africa (Deboudt et al., 2012; Derimian et al., 2008)). Mbour is located on the Atlantic coast, in the Sahelian belt and $80 \mathrm{~km}$ south from Dakar (Figure 2). One major goal of this campaign was to improve our knowledge on the complex aerosol variability and properties in this region. A large set of in-situ and remote sensing instruments was implemented to characterize physico-chemical, optical and radiative properties of particles. Several instruments (lidar, sun/sky photometer, optical counter, Aerosol Chemical Speciation Monitor (ACSM), aethalometer and nephelometer) were used in order to measure or retrieve aerosol properties such as mass concentrations, chemical composition, size distributions, and optical properties in different size fractions. A brief description of each instrument is given in the following paragraphs. This paper focuses on the first part of IOP1 corresponding to a 7- 
week period (March - April 2015) and 43 days of observations during which frequent SB and LLJ events were observed.

\subsection{Ground based in-situ measurements}

Aerosols were sampled through a $\mathrm{PM}_{10}$ inlet and delivered to a comprehensive suite of instruments. Absorption coefficient measurements were performed every minute by an AE16 aethalometer (Magee Scientific, 1 wavelength: $880 \mathrm{~nm}$ ) at dry relative humidity (lower than $40 \%$ during $85 \%$ of the time with a maximum of $53 \%$ reached on April 19, 2015). Aethalometer data have a known scattering interference from particles deposited on the collection filter, and the measurements were post-corrected following the new correction developed by Collaud Coen et al. (2010). Finally the corrected absorption coefficients allowed retrieving BC concentrations (Rivellini et al., 2017). Dry scattering coefficient measurements were also made at $1 \mathrm{~Hz}$ using a three-wavelength nephelometer (Aurora 3000, ECOTECH) operating at 450, 525, and $635 \mathrm{~nm}$ at dry Relative Humidity (RH $<40 \%$ during $85 \%$ of the time). The nephelometer was calibrated using filtered air and $\mathrm{CO}_{2}$ prior to, during, and after the field campaign. The scattering coefficient has been corrected from angular truncation errors and illumination intensity non-idealities based on Müller et al. (2011).

Dry aerosol size distributions were also determined every minute at ground level from 0.01 up to $35 \mu \mathrm{m}$ particle diameters $\left(\mathrm{D}_{\mathrm{p}}\right)$, using a Mini Wide Range Aerosol Spectrometer (Mini-WRAS, model 1371, GRIMM Aerosol GmbH). An optical aerosol spectrometer and a stepping mode operated electrode with Faraday cup electrometer are combined within the Mini-WRAS. Measurements of the particle light scattering ( $D_{p}$ from 0.20 to $35 \mu \mathrm{m}$ ) and the electrical mobility diameter ( $D_{p}$ from 10 to $200 \mathrm{~nm}$ ) can be combined to provide a size distribution over a wide particle diameter range. The Mini-WRAS was calibrated with polystyrene latex spheres (PSL) before and after the campaign. $\mathrm{PM}_{\mathrm{x}}$ concentrations were derived from the particle size distribution using a fixed particle mass density of $1.7 \mathrm{~g} / \mathrm{cm}^{3}$ automatically set by the instrument manufacturer within the algorithm.

Aerosol optical properties are dependent on particle composition and size distribution. In order to take into account the mass concentration of the aerosol population on the optical 30 properties, the Mass Scattering Efficiency (MSE, $\mathrm{m}^{2} \mathrm{~g}^{-1}$ ) is defined (Hand and Malm, 2007). MSE is a key parameter that links dry scattering coefficient $\left(\sigma_{\text {scat,dry }}, \mathrm{Mm}^{-1}\right)$ and mass concentration $\left(M_{d r y}, \mu g m^{-3}\right)$ through Equation 1: 


$$
M S E_{d r y}=\sigma_{s c a t, d r y} / M_{d r y}
$$

Equation 1

Knowing MSE for different aerosol components is crucial to estimate radiative forcing using climate models from aerosol apportionment. The MSE could also be used to identify the different types of aerosols. According to Hand and Malm (2007), for visible wavelengths (near $550 \mathrm{~nm}$ ) within the PM10 fraction, organic aerosol MSE is around $3.5 \pm 0.9 \mathrm{~m}^{2} \mathrm{~g}^{-1}$, mineral dust MSE is around $1.1 \pm 0.4 \mathrm{~m}^{2} \mathrm{~g}^{-1}$ while sea salt MSE is around $2.1 \pm 0.5 \mathrm{~m}^{2} \mathrm{~g}^{-1}$.

The chemical characterization of non-refractory submicron particles $\left(\mathrm{NR}-\mathrm{PM}_{1}\right)$, that is to say material vaporizing around $600^{\circ} \mathrm{C}$ under close-to-vacuum conditions, was performed on-line and in real time every 30 minutes by an ACSM (Aerodyne Research Inc.) equipped with a $\mathrm{PM}_{2.5}$ cut-off inlet (URG Cyclone 2000-30EH, Chapel Hill, NC, USA) and with a primary flow of $3 \mathrm{~L} \mathrm{~min}^{-1}$. This instrument is based on the same principle as the Aerosol Mass Spectrometers (AMS), without providing aerosol size distribution information. A full description of the instrument is available in Rivellini et al. (2017). Under ambient conditions, mass concentrations of particulate organics, sulfate, nitrate, ammonium, and chloride are obtained with a detection limit $<0.2 \mu \mathrm{g} / \mathrm{m}^{3}$ for $30 \mathrm{~min}$ of signal averaging. Middlebrook et al. (2012) algorithm was applied to ACSM mass concentrations to obtain a time-dependent correction of Collection Efficiency (CE) ranging from 0.45 to 0.83 (Rivellini et al., 2017). A minor fraction $(3.2 \%)$ of the data was excluded from the dataset due to unstable parameters, which were generally observed after restarting the instrument following power outages.

20 Positive Matrix Factorization (PMF) of the ACSM organic aerosol spectra was performed using the Multilinear Engine (Paatero and Tapper, 1994) and the Source Finder (SoFi, v.5.3) (Canonaco et al., 2013) operated with IgorPro 6.37 (Wavemetrics). It allows the deconvolution of the organic mass spectra into factors such as Hydrocarbon-like Organic Aerosol (HOA), Cooking Organic Aerosol (COA) and Oxygenated Organic Aerosol (OOA) concentrations. Additionally the latter one can correspond to different oxidization levels (More-Oxidized OOA or MO-OOA, Less-Oxidized OOA or LO-OOA), depending on the fragments attributed to these factors and reflecting their faster or longer processing time in the atmosphere (Lee et al., 2015; Xu et al., 2017).

Meteorological data including temperature, water vapour mixing ratio, and solar 30 radiation were also measured every $10 \mathrm{mn}$ at the sampling site using a meteorological tower (DAVIS Inc weather station, Vantage Pro 2). 


\subsection{Aerosol sampling for in-lab measurements}

Size-segregated sampling of airborne particles was performed for off-line analysis with a 3-stage impactor (Dekati Ltd.), with nominal cut-off sizes (i.e. aerodynamic diameters at $50 \%$ of collection efficiency) at 10, 2.5 and $1.0 \mu \mathrm{m}$, respectively. Particles were collected simultaneously onto Nuclepore ${ }^{\mathrm{TM}}$ polycarbonate membranes and 200-mesh copper TEM grids with carbon type-B supporting films (Ted Pellar, Inc.), at a flow rate of $30 \mathrm{~L} \mathrm{~min}^{-1}$ for about 15 min (this sampling duration was adjusted according to the ambient aerosol load). Samples were sealed in aluminium foil bags and stored at $4{ }^{\circ} \mathrm{C}$ pending analysis.

Single particle analysis by Scanning Electron Microscopy with Energy-Dispersive Xray spectrometry (SEM/EDX) was performed with a JEOL 7100F FEG-SEM equipped with three ultrathin-window $\left(30 \mathrm{~mm}^{2}\right)$ energy-dispersive X-ray detectors (Bruker XFlash 6/30), enabling the analysis of elements with atomic number higher than boron $(Z \geq 5)$. Automated particle analysis was run for about 500 particles per impaction stage using the commercially available Esprit 2.0 system (Bruker®). Spectral acquisitions were performed at $15 \mathrm{kV}$, $300 \mathrm{pA}$ for $20 \mathrm{~s}$. The identification of individual particles is based on their elemental composition obtained from SEM/EDX data as previously described in Derimian et al. (2017). In summary, the analysed particles were classified among four different groups: Dust, Marine, Mixed Dust/Marine, and Other. Particles sorted into the 'Dust' particle group were composed of aluminosilicate (Al- and Si-rich), silicate (Si-rich), calcite (Ca-rich), gypsum (Ca- and Srich), dolomite ( $\mathrm{Ca}$ - and $\mathrm{Mg}$-rich), and Ti-rich particles. The 'Marine' particle group comprises fresh (Na- and Cl-rich) and aged (Cl-depleted) sea salts. Particles that contain sea salts internally mixed with crustal elements were classified into the 'Mixed Dust/Marine' particle type. Particles not assigned to any of the previous particle types were sorted into the 'Other' group.

\subsection{Wind measurements}

The wind field within the lower troposphere $(<5 \mathrm{~km})$ was measured by an eye safe scanning wind lidar (Windcube WLS 100, Leosphere). This pulsed Doppler lidar operates at $1543 \mathrm{~nm}$ with a repetition rate of $10 \mathrm{kHz}$ and uses a heterodyne technique to measure the Doppler shift of laser radiation backscattered by aerosols. More technical details are given by Kumer et al. (2014) and Ruchith and Ernest Raj (2015). During this part of the experiment, continuous monitoring of the wind field between $100 \mathrm{~m}$ and $3 \mathrm{~km}$ (depending on the aerosol 
load) with a $50 \mathrm{~m}$ range resolution was performed. A combination of different scanning programs, including Plan Position Indicator (PPI), Range Height Indicator (RHI) and a Doppler Beam Swinging (DBS) techniques, was used to determine the spatial structure and temporal evolution of the wind field and the vertical profile of the wind vector. The scanning programs was constituted of :

- two $180^{\circ} \mathrm{RHI}$ along east/west and south/north axes with $1^{\circ}$ resolution,

- two $360^{\circ}$ PPI with $2^{\circ}$ resolution at $5^{\circ}$ and $30^{\circ}$ elevation angles,

- a $65^{\circ} \mathrm{PPI}$ with $1^{\circ}$ resolution at a $3^{\circ}$ elevation angle above the sea $\left(225^{\circ}\right.$ to $\left.290^{\circ}\right)$,

- and a $75^{\circ}$ elevation DBS in order to deduce the three components of the wind vector vertical profile.

In our study, the variational method (Iwai et al., 2011) has been applied on the RHI of radial wind speed, along the East/West axe to retrieve the zonal wind component of the seabreeze (Figure 3). This method based on a three-dimensional wind field variational method introduced by Gao et al. (1999) is more flexible to use Doppler data RHI in combination with the DBS data. In order to precisely deduce the structure of the sea-breeze system (sea-breeze gravity current top and front) from RHI of zonal component, we applied the transform covariance method on the slowness zonal component $\mathrm{u}-1$ to each profile. This component corresponds to the reciprocal of the zonal component that tends to be discontinuous in area where the wind speed is equal to zero in a pure sea breeze conditions (Miller et al., 2003) and specially when the sea-breeze front propagation opposites to the prevailing wind (Harmattan) which is the case in our study (Figure 1). We have used the discrete Haar wavelet covariance transform method, which is well suited to identify the transition zones located:

- in the neighbourhood of the sea breeze front when the sea-breeze front propagation opposites to the prevailing wind,

25 - just below shear zone where the flow changes directions from landward to seaward corresponding to the sea-breeze gravity current top.

A collocated 20-Hz ultrasonic anemometer (model USA-1, Metek $\mathrm{GmbH}$ ) providing 3D wind and temperature measurements was deployed on a $10 \mathrm{~m}$ mast to document the blind zone of the lidar.

The meteorological characteristics of the air flows were deduced using the approach of Allwine and Whiteman (1994), which consists in evaluating specific atmospheric transport and diffusion conditions by means of three indicators concepts: stagnation, recirculation, and 
ventilation. These indicators are not real measures of an air mass transport (except under idealized homogeneous wind conditions) but they should be used as characteristics of the flow at the measurement point (Allwine and Whiteman, 1994). They are widely used to estimate flow meteorological characteristics at a study site influenced by local effects such as SB or slope breeze in complex terrain (Al-Khadouri et al., 2015; Chithra and Shiva Nagendra, 2014; Crescenti, 1997; Venegas and Mazzeo, 1999).

To identify these three types of airflow conditions, integral quantities are defined over a certain 'transport period', on the basis of the meridional $\mathrm{v}_{\mathrm{j}}$ and zonal $\mathrm{u}_{\mathrm{j}}$ components of the wind as observed at time $t_{j}$ ( $j$ being the index of the point in the dataset) with the sampling interval $\tau$ of $\mathrm{N}$ discrete data points. The wind vector sum $\mathrm{L}_{\mathrm{ip}}$ and scalar sum $\mathrm{S}_{\mathrm{ip}}$ also called 'resultant transport distance' and 'wind run', respectively, were calculated according to Equations 2 and 3:

$$
\begin{aligned}
& L_{i p}=\tau\left[\left(\sum_{j=i}^{i+p} u_{j}\right)^{2}+\left(\sum_{j=i}^{i+p} v_{j}\right)^{2}\right]^{\frac{1}{2}} \\
& S_{i p}=\tau \sum_{j=i}^{i+p}\left(u_{j}^{2}+v_{j}^{2}\right)^{\frac{1}{2}}
\end{aligned}
$$

$$
\text { With } i=1, \ldots, N-P+1 \text { and } 0<P<N
$$

$\mathrm{L}_{\mathrm{ip}}$ and $\mathrm{S}_{\mathrm{ip}}$ represent, respectively, the distance travelled by the air mass in a straight line from the beginning up to the end of the trajectory and the total distance travelled by the air mass during the desired transport period $T=P \tau$. The recirculation factor $\mathrm{R}_{\mathrm{ip}}$, evolving between 0 and 1 , is based on the ratio between these wind vector sum $L_{i p}$ and scalar sum $S_{i p}$ over the given transport period T, as expressed in Equation 4:

$$
R_{i p}=1-\frac{L_{i p}}{S_{i p}}
$$

Equation 4

Thereby, recirculation conditions ( $\mathrm{R}_{\mathrm{ip}}$ equal to 1 ) corresponding to a state of the atmosphere where a polluted air mass is initially transported away from the observation site, but returns later to the site neighbourhood ( $\left.\mathrm{L}_{\mathrm{ip}}<<\mathrm{S}_{\mathrm{ip}}\right)$, where pollutants accumulate, and could produce high levels of air pollution concentrations.

A 24-hour transport period has been commonly used in past studies to estimate atmospheric transport and diffusion conditions (Levy et al., 2009; Nankar et al., 2009; Pérez et al., 2011; Russo et al., 2016; Surkova, 2013). However, shorter time periods are more appropriate to detect small-scale specific atmospheric conditions and study in detail aerosol 
variability after rapid transition of atmospheric dynamics. Here, we propose to deduce the integral quantities Lip, Sip and Rip by varying the transport period T from 1 hour to 24 hours at the observation site by using ultrasonic anemometer measurements. Furthermore, above the sea, only Sip has been deduced from the $65^{\circ}$ PPI performed between $225^{\circ}$ and $290^{\circ}$ azimuthal angles by using the velocity-azimuth processing technique (Shapiro et al., 2003).

\section{Results and discussions}

\subsection{General air mass characteristics of the IOP1}

North-western Africa is mainly dominated by maritime and continental trades during the winter and spring seasons (November to April) until the monsoon starts (Leroux, 2001). Depending on wind directions, aerosol types observed over this site could be dominated by desert dust, sea salt, biomass burning or urban particles. During the first intensive observation period (IOP1) of the SHADOW campaign, the wind over Mbour at the ground, had two major regimes: maritime trades ( 25\%), coming from the North-West, and continentalized maritime trades ( $40 \%$ ), coming from the North to North-North-East directions (Figure 4a).

Maritime trades are mainly observed up to $300 \mathrm{~m}$ (Figure $4 \mathrm{a}$ and $4 \mathrm{~b}$ ) whereas continentalized trades are detected up to $1000 \mathrm{~m}$ with relatively high speed reaching more than $20 \mathrm{~m} / \mathrm{s}$ particularly in the altitude between $300 \mathrm{~m}$ and $500 \mathrm{~m}$ corresponding to the LLJ height (figures 4a-4e). During the early morning, maximum wind speeds have been measured. Wind speed vertical gradient, of 0.04-0.07 $\mathrm{s}^{-1}$, are observed corresponding to high wind shear effect generated by the LLJ phenomenon. Above $1000 \mathrm{~m}$, the wind direction veers with height to continental trades (Harmattan, NE to E, Figure 4e and 4h) indicating the presence of warm air advection from the north-eastern/eastern dry lands (Parker et al., 2005) that can be associated with long-range transport of desert dust from the Sahelian and Saharan source regions.

At ground level, three dust events were identified during IOP1 corresponding to Harmattan dust transport from the sources located in the Sahelian band and Saharan Desert towards West Africa: 15-22 March, 29-4 April and 10-11 April. These dust events observed over Mbour lasted from 2 days to a full week and were characterized by high AOD values (between 1 and 2) associated with high extinction coefficients at the surface (up to $600 \mathrm{Mm}^{-1}$ ) and low values of the Ångström Exponent, characteristic of coarse particles. During these dust events, $\mathrm{PM}_{10}$ concentrations reached values up to $1000 \mu \mathrm{g} \mathrm{m}^{-3}$. 
SB episodes were also observed, coming from WSW to WNW, during 28 days out of 43 days and representing $20 \%$ of the total observation time. These episodes have been identified by a large increase of the water vapour mixing ratio (up to $15 \mathrm{~g} \mathrm{~kg}^{-1}$ ), a large decrease of the temperature (about $10^{\circ} \mathrm{C}$ ) as well as a rapid change in wind direction (from E/ENE to mainly $\mathrm{W}$ below $300 \mathrm{~m}$ during Harmattan events). SB occurred during the afternoon and lasted on average for 5 hours, usually from 13:30 to 18:00 UTC (corresponding to local time). In some cases, the strong Harmattan (opposite to the SB) delayed the SB occurrence (by $15 \mathrm{~min}$ to one hour). The SB front blockade, during this longer SB establishment period, could conduct to air mass stagnation (i.e. a relatively high atmospheric residence time). These air masses are, on average and in comparison to maritime and continental trades, enriched in fine particles $\left(\mathrm{PM}_{1}\right)$ and depleted in absorbing ones.

LLJ events were observed during 39 nights out of 43 days. LLJ are wind speed maxima which occur within the residual layer (the remnants of the daytime boundary layer) when the wind is decoupled from the land surface. However, LLJ may influence the exchange processes between the surface and the atmosphere, due to turbulences generated by wind shear within the layer located below the jet (Banta et al., 2003; Van de Wiel et al., 2003). During the IOP1, LLJ were coming from NNW to E sectors and lasted, on average, for 19 hours from 17:30 UTC to noon the day after. The mean LLJ core speed (corresponding to the height of the maximum LLJ wind speed) was about $15 \mathrm{~m} \mathrm{~s}^{-1}$ but could reach up to $24 \mathrm{~m} \mathrm{~s}^{-1}$, particularly during the early morning. The jet core height is observed between 200 and $400 \mathrm{~m}$ for more than $60 \%$ of the events. The complexity of the dynamical circulation due to the interactions between the SB, the LLJ and the Harmattan flows induces a high variability of aerosol physico-chemical characteristics. Thereafter, two typical case studies are presented to better understand the impact of the SB and LLJ effects on the temporal evolution of aerosol properties: the first one was observed on 28 March 2015 under typical Harmattan conditions, while the second one, observed on 31 March 2015, corresponds to specific Harmattan conditions with air masses enriched in dust particles.

\subsection{Case study out of dust event: 28 March 2015}

The time-height cross-section of the horizontal wind direction and speed on 28 March 2015 (Figure 5a) illustrates the atmospheric dynamics observed over Mbour, in the absence of dust event. The Northerly LLJ was detected at night with a jet core height of $200 \mathrm{~m}$ and a core speed of $\sim 13 \mathrm{~m} \mathrm{~s}^{-1}$. During the early morning (3:00 UTC), the Harmattan settled and this jet 
strengthened while the jet layer deepened (200-600 m). At ground level, the air mass was, first of all, a mix between the Northerly LLJ and the Harmattan with a water vapour mixing ratio of about $8 \mathrm{~g} \mathrm{~kg}^{-1}$ (Figure 6a). Then, the drier Harmattan air mass progressively reached ground level, which led to a decrease of the water vapour mixing ratio that dropped a minimum below $5 \mathrm{~g} \mathrm{~kg}^{-1}$ around 11:00 UTC. Simultaneously, the Harmattan attenuated and then the SB started rapidly at 14:30 UTC. The SB establishment period lasted about 30 minutes and was associated with a sharp increase of the water vapour mixing ratio from $\sim 4$ to $16 \mathrm{~g} \mathrm{~kg}^{-1}$ (Figure 6a).. Finally, the SB disappeared at 20:30 UTC, when the Northerly LLJ appeared below $400 \mathrm{~m}$, identified by the sharp decrease of the water vapour mixing ratio that last for few minutes.

The aerosol mass concentration (Figure 6a and Table 1) was strongly dependent on the atmospheric dynamics in addition to the temporal variability of aerosol sources. A "morning peak" was clearly observed on that day between 7:00 and 9:00, with $\mathrm{PM}_{10}, \mathrm{PM}_{2.5}$ and $\mathrm{PM}_{1}$ reaching 155, 66 and $25 \mu \mathrm{g} \mathrm{m}^{-3}$ respectively, while the daily averages were around 64, 30 and $13 \mu \mathrm{g} \mathrm{m}^{-3}$. This peak was regularly observed at this time during the campaign and was not due to an evolution of the atmospheric circulation, but rather to an intensification of local anthropogenic activities generating an increased contribution of local pollution (Rivellini et al., 2017). Figure $6 \mathrm{~b}$ shows the time series of the mass scattering efficiency (MSE, RH <40\%) along with the water vapour mixing ratio. The morning PM peak coincides with a sharp decrease of MSE, within the $\mathrm{PM}_{10}$ fraction, from more than 2.5 to less than $1.5 \mathrm{~m}^{2} \mathrm{~g}^{-1}$, that can be explained by a higher contribution of resuspended coarse dust from road-traffic. Indeed, organic matter associated to higher MSE often dominates the fine fraction at Mbour, while the coarse fraction associated with lower MSE is dominated by sea salt and/or dust (Flament et al., 2011; Rivellini et al., 2017). This is corroborated by a decrease of the $\mathrm{PM}_{1} / \mathrm{PM}_{10}$ ratio, which dropped from 0.25 just before this pollution event to 0.16 during the pollution peak (Table 1).

The SB arrival around 14:30 did not alter the $\mathrm{PM}_{10}$ concentration, which remained relatively constant right before $\left(51 \mu \mathrm{g} \mathrm{m}^{-3}\right)$, during $\left(59 \mu \mathrm{g} \mathrm{m}^{-3}\right)$ and after $\left(52 \mu \mathrm{g} \mathrm{m}^{-3}\right)$ the $\mathrm{SB}$ establishment (Figure 6a, and Table 1). Over all SB cases observed during the IOP1, an evolution of $\mathrm{PM}_{10}$ concentration after the SB establishment is rare (2 cases out of 28 ). In contrast, the $\mathrm{PM}_{2.5}$ and $\mathrm{PM}_{1}$ concentrations, respectively at 25.5 and $7.95 \mu \mathrm{g} \mathrm{m}^{-3}$, before the SB establishment, reached 32.3 and $18.4 \mu \mathrm{g} \mathrm{m}^{-3}$ during the SB period (Table 1). This large increase of the finer fractions was observed for all the SB cases recorded in Mbour during the 
IOP1 and is consistent with previous studies (Moorthy et al., 1993; Pérez et al., 2010; Rodríguez et al., 2008).

During the SHADOW campaign, sulfate concentration within the $\mathrm{PM}_{1}$ fraction was found to be a good proxy for marine influence (Rivellini et al., 2017). Indeed, within a marine atmosphere, various sulfur-containing compounds have the potential to create new aerosols and/or, depending on the environmental conditions, condense onto existing particles (Kulmala et al., 2011). On the other hand, Black Carbon (BC) is produced by incomplete combustion of fossil fuel and biomass and is therefore a good proxy for anthropogenic aerosols (Figure 6c). During SHADOW, Rivellini et al. (2017) have shown that OM, BC and Chl maximum concentrations are associated with similar wind regimes highlighting a common origin of the higher concentrations for these species. Their results indicate that $\mathrm{OM}, \mathrm{BC}$ and $\mathrm{Chl}$ higher concentrations, especially during the sea breeze, could come from anthropogenic emissions from Dakar and possibly from maritime traffic along the western African coast.

The organic and sulfate concentrations, within the $\mathrm{PM}_{1}$ fraction measured by the ACSM, increased by a factor up to 8 during SB (Figure $7 \mathrm{a}$ and $\mathrm{b}$ and Table 1): $\mathrm{SO}_{4}$ concentrations that were $0.29 \mu \mathrm{g} \mathrm{m}^{-3}$ before the $\mathrm{SB}$ establishment increased up to $2.32 \mu \mathrm{g} \mathrm{m}^{-3}$ afterward; whereas the organic concentrations (sum of the PMF OA factors, Figure 7b) were around $0.74 \mu \mathrm{g} \mathrm{m}^{-3}$ prior to the SB establishment and reached $5.84 \mu \mathrm{g} \mathrm{m}^{-3}$ after the SB front passage. Figure $7 \mathrm{c}$ shows the organic factor contribution as a function of time. Before the SB establishment, the MO-OOA fraction is low (0.15), especially during the morning peak suggesting fresh and local emission of organic. The MO-OOA fraction reached a maximum (0.56) during the SB establishment and stabilized during the SB period around 0.4 to the detriment of COA. The MO-OOA increase implies that the formation of secondary organic aerosols was greatly enhanced during the SB period.

This relatively high contribution of marine sources to the submicron fraction during SB was also observed for the larger fraction (1-2.5 $\mu \mathrm{m}$ ) using electron microscopy (Figure 8). As expected, the relative proportion of marine particles was higher during SB (61\% of analysed particles) than before it (21.2\% of analysed particles). However, in contrast with air mass collected before SB, most of marine particles collected during the SB contained a relatively high content of nitrogen and sulphur, which probably indicates a contribution of local anthropogenic activities. These marine particles were liquid in the atmosphere, as indicated by the "halo" observed around them by microscopy (Figure 8b, blue arrow). An increase of their relative proportion sharply modified the MSE of $\mathrm{PM}_{10}$ (Figure 6b), most probably due to 
physical and chemical evolution of the aerosols exposed to a high water vapour-mixing ratio and to condensable gases (such as $\mathrm{SO}_{2}$ and organics).

This marine influence is also observed with the dynamic fields. Indeed, the maximum recirculation factor $\mathrm{R}(0.84)$ on that day is detected at about 19:00 at the observation site near ground for a transport period of about 7 hours. This factor depicts high recirculation conditions during breezes, meaning that the Harmattan transported the air mass toward the sea during the early afternoon while the SB brought it back over land. In addition, the influence of marine air masses on the aerosol observed at Mbour were confirmed by the wind run parameter $\left(S_{\mathrm{ip}}\right)$ which can be used as an indication of stagnation (Kim et al., 2007). Figure 9 represents the wind run evolution deduced from the Doppler lidar PPI scan obtained over the sea (westward) just before the SB arrival at Mbour and for a transport period of 1 hour. Low values of $S_{\text {ip }}(<8 \mathrm{~km})$ indicate that horizontal wind speed was very low, favouring stagnation conditions (1-hour residence time). The $S_{\text {ip }}$ lowest value is observed over the sea $(550-750 \mathrm{~m})$ and may suggest the presence of the SBF. In this range from the coast, confrontation between the SBF and the opposing wind (Harmattan) may favour stagnation conditions. The Harmattan may inhibit the SBF propagation and may generate an area where the wind is calm which is confirmed by the $S_{\text {ip }}$ lowest value. Therefore, before coming back at the observation site, the air masses stagnated over the sea and thus could largely be influenced by marine air.

Later in the afternoon, the occurrence of the LLJ modifies the structure of the SB and is associated with the increase of vertical heat flux and momentum flux (not shown here), deduced from the sonic anemometer. This increase, observed during the LLJ effect period, suggested vertical mixing process between the LLJ and the GC, which is consistent with the decrease of water mixing ratio and increase of temperature at ground.

In parallel, the LLJ effect implied a new modification of atmospheric particle properties for the rest of the day. Although, the LLJ establishment period duration was very short (19:30 - 20:00 UTC), the LLJ onset might have impacted the aerosol properties at ground level due to vertical mixing induced by the jet. This mixing process led to a decrease of both the $\mathrm{PM}_{1} / \mathrm{PM}_{10}$ ratio (Table 1: from 0.35 during SB to $\sim 0.15$ during the LLJ establishment period) and the $\mathrm{SO}_{4} / \mathrm{BC}$ ratio (Figure $6 \mathrm{c}$, from 3.1 during $\mathrm{SB}$ to $\sim 1.6$ during the LLJ establishment period). Likewise, the COA/MO-OOA ratio (Figure 6c) was stable and relatively low (around 0.7) during the SB period but reached 2.55 during the LLJ establishment period. This suggests a large contribution of local anthropogenic emissions prevailing over the regional emission of Secondary Organic Aerosols (SOA). Consequently, the relative increase of the continental 
aerosol during this LLJ establishment period lowered the MSE within the $\mathrm{PM}_{10}$ fraction towards values that are more characteristics of dust (Figure $6 \mathrm{~b}$, from $\sim 2.4$ during SB to $\sim 1.5$ during the LLJ establishment period, Hand and Malm, 2007).

3.3. Case study during a dust event: 31 March 2015

During dust events, the Harmattan flow is steadily settled all day long and is seldom perturbed near the ground by the SB or by the Northerly LLJ flows, excepted for a few events such as the one presented in this section. The atmospheric dynamics of the 31 March case is illustrated by the time-height cross-section of the horizontal wind direction and speed (Figure $5 b$ ). At night, the Easterly Harmattan jet was mainly observed in the lower troposphere (< $2000 \mathrm{~m}$ ) with a high core speed (> $15 \mathrm{~m} \mathrm{~s}^{-1}$ ) located between 200 and $500 \mathrm{~m}$ above ground. After sunrise (7:00 UTC), the Harmattan jet core rose up to 400-1000 m at 10:00 UTC before the jet vanished progressively after 11:00 UTC. However, even after the jet disappearance, the Harmattan flow prevailed near ground during a large part of this day, until the SB occurrence at 15:30 UTC. The SB layer depth increased progressively up to $1100 \mathrm{~m}$ and collapsed at 19:00 UTC due to the Northerly LLJ occurrence with a jet core height located at $500 \mathrm{~m}$. This LLJ arrival, in altitude, may imply mixing processes between the surface layer (marine air mass) and upper layers (continental air from the Harmattan flow) until 21:00 UTC corresponding to the LLJ effect period.

With a daily average concentration $\sim 200 \mu \mathrm{g} \mathrm{m}^{-3}$, the $\mathrm{PM}_{10}$ concentrations were much higher, by a factor of 4 , on this day than during the previous case study (Figure 6 a and d). These high concentrations were due to a desert dust event that started two days before (29 March) and lasted for one full week. The air mass was also much drier during this dust event, with a twice-lower water vapour mixing ratio $\left(4 \mathrm{~g} \mathrm{~kg}^{-1}\right)$ during the morning, before the SB onset.

During this case study, the aerosol mass concentration evolution is extremely different from that of the situation without dust event (Table 1). Firstly, as the desert dust particles account for a large share of the PM, the aerosol is dominated by the coarse fraction. Therefore, very low values of the $\mathrm{PM}_{1}$ to $\mathrm{PM}_{10}$ ratio ( 0.14) were observed during the periods of undisturbed Harmattan flow (00:00 and 06:00 UTC). The PM background concentrations were very high during the whole dust event so that the "morning peak" (07:00-09:00 UTC) represented only a relatively small increase, even though the $\mathrm{PM}_{10}, \mathrm{PM}_{2.5}$ and $\mathrm{PM}_{1}$ concentrations reached 331 , 
139 and $42 \mu \mathrm{g} \mathrm{m}^{-3}$, respectively. However, even if the morning peak did not lead to a large concentration increase, it clearly impacted the aerosol composition: the input of dust from local pollution during the peak was associated with an increase of organic compounds (HOA) (see Table 1), that generated a small decrease of the MSE within the $\mathrm{PM}_{10}$ fraction up to $\sim 1.5 \mathrm{~m}^{2} \mathrm{~g}^{-1}$ (Figure 6e), a value similar to the one observed during the morning pollution peak in the absence of dust event (Figure 6b).

The SB arrival was detected at 15:30 UTC, corresponding to a sharp increase of the water vapour mixing ratio and associated with an increase of $\mathrm{PM} . \mathrm{PM}_{10}, \mathrm{PM}_{2.5}$ and $\mathrm{PM}_{1}$ respectively rose from $118.8,67.2$ and $20.5 \mu \mathrm{g} \mathrm{m}^{-3}$ just before the SB onset to 182.6, 95.4 and $32.5 \mu \mathrm{g} \mathrm{m}^{-3}$ during the SB (Figure 6 and Table 1). This evolution also coincided with an increase of the organic and sulfate concentrations within the $\mathrm{PM}_{1}$ fraction, measured by the ACSM : prior to the SB establishment, the $\mathrm{SO}_{4}$ (organic) concentrations were around 0.24 $\mu \mathrm{g} \mathrm{m}^{-3}\left(0.96 \mu \mathrm{g} \mathrm{m}^{-3}\right)$, while after the SB front passage, they reached $0.79 \mu \mathrm{g} \mathrm{m}^{-3}\left(6.2 \mu \mathrm{g} \mathrm{m}^{-3}\right)$. The $\mathrm{SO}_{4}$ concentrations were significantly lower than the maxima observed in the absence of dust event (2.32 $\mathrm{\mu g} \mathrm{m}^{-3}$ during SB on 28 March, Table 1), suggesting a lower influence of marine air masses in this period of strong continental Harmattan flow. This fact is also supported by a lower $\mathrm{SO}_{4} / \mathrm{BC}$ ratio during the $\mathrm{SB}$ (Figure $6 \mathrm{f}$ ) and an increase of the $\mathrm{COA} / \mathrm{MO}-\mathrm{OOA}$ ratio, which is associated with a growing influence of local anthropogenic emission (COA, Figure 7f). Unlike the first case, the OOA (MO-OOA+LO-OOA) fraction is less important during the SB with anthropogenic and freshly oxidized (LO-OOA) organics predominating over MO-OOA (decreasing from 0.62 before the SB establishment to 0.3 during the SB). This could be explained by the stagnation of the air mass closer to the coast which leads to (i) a more prominent supply of primary (less oxidized) particles to the aerosol burden; and (ii) less supply of aged (more oxidized) marine air masses during the SB compared to the previous case.

The recirculation factor $\mathrm{R}$ reached a maximum of 0.98 for a 9-hour transport period ending around 20:30 UTC. This implies that the air mass observed between the SB occurrence and 20:30 was possibly the same one as the one sampled from 11:30 UTC until the SB arrival. This effect is clearly visible on the three $\mathrm{PM}_{\mathrm{x}}$ concentrations (Figure $6 \mathrm{~d}$ ) that decreased after the morning peak and then increased after the SB occurrence, roughly reaching back at 20:30 UTC the levels observed at 11:30 $\left(\mathrm{PM}_{10}=210 \mu \mathrm{g} \mathrm{m}^{-3} ; \mathrm{PM}_{2.5}=100\right.$ $\left.\mu \mathrm{g} \mathrm{m}^{-3} ; \mathrm{PM}_{1}=30 \mu \mathrm{g} \mathrm{m}^{-3}\right)$. Interestingly, the linear slopes of the $\mathrm{PM}_{10}$ decrease $\left(-0.38 \mu \mathrm{g} \mathrm{m}^{-}\right.$ ${ }^{3} \min ^{-1}$ ) and increase $\left(0.45 \mu \mathrm{g} \mathrm{m}^{-3} \mathrm{~min}^{-1}\right.$ ) were very similar (same tendencies observed for 
$\mathrm{PM}_{2.5}$ and $\mathrm{PM}_{1}$ linear slopes), which reinforces the hypothesis that the same air mass was transported back and forth over the measurement site. Besides, the lesser influence of marine air masses on the dust event case could be confirmed by the wind run parameter $\left(\mathrm{S}_{\mathrm{ip}}\right)$ computed just before the SB arrival for a transport period of 1 hour (Figure 9): the low values $(<8 \mathrm{~km})$ indicating stagnant conditions (1-hour residence time) prevailed only very near the coast and land for this case (200-250 m against 550-750 $\mathrm{m}$ for the previous case). This may suggest that the SBF propagation is inhibited very close to the coast favouring calm wind area in the vicinity of the SBF.

All these aerosol property alterations before and during SB were also reflected in the high temporal variability of the MSE (Figure 6e). The different MSE values combined with the chemical composition allowed us to identify periods when (i) organics were predominant within the $\mathrm{PM}_{1}$ (Figure 7e and Table 1: during the SB period) corresponding to very high $\operatorname{MSE}\left(>2.5 \mathrm{~m}^{2} \mathrm{~g}^{-1}\right)$, (ii) dust were predominant within the $\mathrm{PM}_{10}$ (late night and morning) corresponding to high MSE (> $1.5 \mathrm{~m}^{2} \mathrm{~g}^{-1}$ ). One can note that the MSE increase at the arrival of the SB was sharper during the dust event case than in the absence of dust. The effective radius (calculated as the ratio of the $3^{\text {rd }}$ and $2^{\text {nd }}$ moments of the Mini-WRAS aerosol size distribution) was on average $0.25 \pm 0.12 \mu \mathrm{m}$ and $0.81 \pm 0.20 \mu \mathrm{m}$ and the $\mathrm{PM}_{10}$ to $\mathrm{PM}_{1}$ ratio was equal to 2.85 and 5.62 during the SB periods of the "without dust" and "dust event" cases respectively. However, Hand and Malm (2007) showed that larger particles from urban, rural and marine origins are associated with lower MSE while we observed the opposite tendency. Therefore, the chemical composition of those aerosols is necessarily playing a major role.

Later in the afternoon, the LLJ effect period was observed from 19:00 UTC to 21:00 UTC (Figure 5b). As for the case study without dust event, the occurrence of the LLJ modified the structure of the SB, favouring vertical mixing process between the LLJ and the GC. This LLJ was responsible for (i) a sharp increase of PM concentrations (notably the coarse fraction, Figure 6d), (ii) a decrease of the $\mathrm{SO}_{4} / \mathrm{BC}$ ratio (Figure 6f) associated to a lesser influence of marine air masses, and (iii) a large increase of the COA/MO-OOA ratio associated with a larger influence of local anthropogenic emissions (Figure 6f). Consequently, as for the previous case, the increase of the relative proportion of dust during this LLJ establishment period modified the MSE of $\mathrm{PM}_{10}$ (Figure 6e) toward lower values (from 2.5 at the beginning of the SB event to $\sim 1.4$ during the LLJ establishment period) that are more characteristic of dust (Hand and Malm, 2007). 


\section{Conclusions}

This paper describes the aerosol variability due to specific atmospheric dynamical features regularly observed during the IOP1 of the SHADOW campaign over Mbour (coastal region of Senegal), using a combination of in-situ and remote sensing observations. The insitu samplers and instruments provided the chemical composition, the coarse optical properties and the physical properties of the aerosols. Coincidently, a scanning wind lidar combined with a sonic anemometer, measured the wind field within the lower troposphere.

Complex circulations of different flows involving Easterly Harmattan, Northerly Low Level Jet and Westerly Sea Breeze, have been identified during the period. The interaction between these flows implied a high variability of the aerosol physico-chemical characteristics and two case studies were selected. The first study case is representative of SB events observed during typical Harmattan conditions without dust event, while the second highlights a SB event during a Harmattan desert dust transport event. Both cases show a strong influence of the SB on the aerosol properties. SB events coincided with an increase in organic and sulfate concentrations within PM1 fraction, good markers of anthropogenic and marine influences, respectively. Marine particles from the $1-2.5 \mu \mathrm{m}$ fraction collected during SB were also associated with higher nitrogen and sulphur contents indicating the contribution of anthropogenic activities. Moreover, high recirculation factors over 0.8 have been computed and the dry Mass Scattering Efficiency increases during the SB, for both cases, by a factor of 1.4. Given the fact that SB phenomena occurs every other day at Mbour during at least 3 hours and that the relative humidity may reach $96 \%$, the effect of such events on the aerosol radiative forcing may not be negligible.

Both cases show some specific dynamical evolution features at ground level. Indeed, the air mass stagnation area, observed just before the SB onset (over the land), could remain very close to the coast (31th March) or could extend farther over the sea ( $28^{\text {th }}$ March). Before the occurrence of the SB over the land, the anthropogenic air mass is transported from the land to the sea by the Harmattan. Then, this air mass seaward propagation is weakened in the neighbourhood of the SBF, which is opposed to the Harmattan. The confrontation between the SBF and the opposing wind (Harmattan) may favour stagnation conditions located over the sea for the 28th March and very close to the coast for the 31st March. The stagnation condition location depends on the strength of the opposing wind, which inhibits the SBF propagation and generates a wind calm area in the neighbourhood of the SBF. 
This difference has a strong impact on the aerosol evolution. Indeed, the environment over the sea, humid and enriched in condensable gases, is highly favourable to aerosol coating and particle aging. The air mass stagnation over the sea is associated with an increase in the concentrations of organic species in the finer aerosol fractions $\left(\mathrm{PM}_{1}\right)$ and notably the More Oxidized Oxygenated Organic Aerosol fraction (MO-OOA), due to an increased contribution of anthropogenic sources (from Dakar and possibly from maritime traffic (Rivellini et al., 2017)) and the formation of secondary organic aerosols. While, when stagnation occurs closer to the coast, the influence of marine air is less important. As a result $\mathrm{PM}_{1}$ or $\mathrm{PM}_{2.5}$ concentrations increase less and the Cooking Organic Aerosol (COA) on MO-OOA ratio indicates an influence of local anthropogenic emission. SB events are then not necessarily associated to new formation of aerosols as previously found (Piazzola et al., 2012; Rodríguez et al., 2008).

Moreover, during the LLJ onset in altitude (LLJ effect periods), $\mathrm{PM}_{10}$ and absorption coefficient observed at ground level increased dramatically (up to a factor of 2), probably due to the vertical processes between the surface and the LLJ, which transported dust and local anthropogenic emissions, notably cooking-like organic aerosol or waste burning emissions. SB events are common over coastal regions and their influence on aerosol depends mainly on the dynamical features over the region. Wind profile measurements coupled with aerosols measurements are then essential to better understand sea breeze effects on aerosol variability and properties. Similar studies at different coastal locations around the globe would help to better implement this phenomenon in current global aerosol models.

\section{Acknowledgements}

LHR's $\mathrm{PhD}$ grant and the SHADOW campaign have been financially supported by the CaPPA project (Chemical and Physical Properties of the Atmosphere), which is funded by the French National Research Agency (ANR) through the PIA (Programme d'Investissement d'Avenir) under contract "ANR-11-LABX-0005-01", by the Regional Council "Hauts-deFrance" and the European Regional Development Fund (ERDF).

Al-Khadouri, A., Al-Yahyai, S., Charabi, Y., 2015. Contribution of atmospheric processes to the degradation of air quality: case study (Sohar Industrial Area, Oman). Arab. J. Geosci. 8, 1623-1633. 
Allwine, K.J., Whiteman, C.D., 1994. Single-station integral measures of atmospheric stagnation, recirculation and ventilation. Atmos. Environ. 28, 713-721. https://doi.org/10.1016/1352-2310(94)90048-5

Andreae, M.O., Crutzen, P.J., 1997. Atmospheric Aerosols: Biogeochemical Sources and Role in Atmospheric Chemistry. Science 276, 1052-1058. https://doi.org/10.1126/science.276.5315.1052

Atkins, N.T., Wakimoto, R.M., Weckwerth, T.M., 1995. Observations of the SeaBreeze Front during CaPE. Part II: Dual-Doppler and Aircraft Analysis. Mon. Weather Rev. 123, 944-969. https://doi.org/10.1175/1520-0493(1995)123<0944:OOTSBF>2.0.CO;2

Augustin, P., Delbarre, H., Lohou, F., Campistron, B., Puygrenier, V., Cachier, H., Lombardo, T., 2006. Investigation of local meteorological events and their relationship with ozone and aerosols during an ESCOMPTE photochemical episode. Ann. Geophys. 24, 28092822.

Babu, S.S., Kompalli, S.K., Moorthy, K.K., 2016. Aerosol number size distributions over a coastal semi urban location: Seasonal changes and ultrafine particle bursts. Sci. Total Environ. 563-564, 351-365. https://doi.org/10.1016/j.scitotenv.2016.03.246

Banta, R.M., Senff, C.J., White, A.B., Trainer, M., McNider, R.T., Valente, R.J., Mayor, S.D., Alvarez, R.J., Hardesty, R.M., Parrish, D., Fehsenfeld, F.C., 1998. Daytime buildup and nighttime transport of urban ozone in the boundary layer during a stagnation episode. J. Geophys. Res. 103, 22. https://doi.org/10.1029/98JD01020

Bond, T.C., Streets, D.G., Yarber, K.F., Nelson, S.M., Woo, J.-H., Klimont, Z., 2004. A technology-based global inventory of black and organic carbon emissions from combustion. J. Geophys. Res. Atmospheres 109, D14203. https://doi.org/10.1029/2003JD003697

Bovchaliuk, V., Goloub, P., Podvin, T., Veselovskii, I., Tanre, D., Chaikovsky, A., Dubovik, O., Mortier, A., Lopatin, A., Korenskiy, M., Victori, S., 2016. Comparison of aerosol properties retrieved using GARRLiC, LIRIC, and Raman algorithms applied to multiwavelength lidar and sun/sky-photometer data. Atmos Meas Tech 9, 3391-3405. https://doi.org/10.5194/amt-9-3391-2016

Brown, S.S., Dubé, W.P., Osthoff, H.D., Wolfe, D.E., Angevine, W.M., Ravishankara, A.R., 2007. High resolution vertical distributions of NO3 and N2O5 through the nocturnal boundary layer. Atmos Chem Phys 7, 139-149. https://doi.org/10.5194/acp-7-139-2007 
Canonaco, F., Crippa, M., Slowik, J.G., Baltensperger, U., Prévôt, A.S.H., 2013. SoFi, an IGOR-based interface for the efficient use of the generalized multilinear engine (ME-2) for the source apportionment: ME-2 application to aerosol mass spectrometer data. Atmospheric Meas. Tech. 6, 3649.

Chithra, V.S., Shiva Nagendra, S.M., 2014. Impact of outdoor meteorology on indoor PM10, PM2.5 and PM1 concentrations in a naturally ventilated classroom. Urban Clim. 10, 77-91. https://doi.org/10.1016/j.uclim.2014.10.001

Christopher, S.A., Gupta, P., Haywood, J., Greed, G., 2008. Aerosol optical thicknesses over North Africa: 1. Development of a product for model validation using Ozone Monitoring Instrument, Multiangle Imaging Spectroradiometer, and Aerosol Robotic Network. J. Geophys. Res. Atmospheres 113, D00C04. https://doi.org/10.1029/2007JD009446

Collaud Coen, M., Weingartner, E., Apituley, A., Ceburnis, D., Fierz-Schmidhauser, R., Flentje, H., Henzing, J.S., Jennings, S.G., Moerman, M., Petzold, A., others, 2010. Minimizing light absorption measurement artifacts of the Aethalometer: evaluation of five correction algorithms. Atmospheric Meas. Tech. 3, 457-474.

Crawford, J., Cohen, D.D., Griffiths, A.D., Chambers, S.D., Williams, A.G., Stelcer, E., 2017. Impact of atmospheric flow conditions on fine aerosols in Sydney, Australia. Aerosol Air Qual. Res. 17, 1746-1759+.

Crescenti, G.H., 1997. Meteorological measurements during the Lower Rio Grande Valley environmental study. Environ. Int., Environmental Aspects of the Lower Rio Grande Valley 23, 629-642. https://doi.org/10.1016/S0160-4120(97)00066-4

Darby, L.S., 2005. Cluster Analysis of Surface Winds in Houston, Texas, and the Impact of Wind Patterns on Ozone. J. Appl. Meteorol. 44, 1788-1806. https://doi.org/10.1175/JAM2320.1

Deboudt, K., Gloter, A., Mussi, A., Flament, P., 2012. Red-ox speciation and mixing state of iron in individual African dust particles. J. Geophys. Res. Atmospheres 117. https://doi.org/10.1029/2011JD017298

Delgado, R., Rabenhorst, S.D., Demoz, B.B., Hoff, R.M., 2015. Elastic lidar measurements of summer nocturnal low level jet events over Baltimore, Maryland. J. Atmospheric Chem. 72, 311-333.

Derimian, Y., Choël, M., Rudich, Y., Deboudt, K., Dubovik, O., Laskin, A., Legrand, 
M., Damiri, B., Koren, I., Unga, F., Moreau, M., Andreae, M.O., Karnieli, A., 2017. Effect of sea breeze circulation on aerosol mixing state and radiative properties in a desert setting. Atmos Chem Phys Discuss 2017, 1-37. https://doi.org/10.5194/acp-2016-1084

Derimian, Y., Léon, J.-F., Dubovik, O., Chiapello, I., Tanré, D., Sinyuk, A., Auriol, F., 5 Podvin, T., Brogniez, G., Holben, B.N., 2008. Radiative properties of aerosol mixture observed during the dry season 2006 over M'Bour, Senegal (African Monsoon Multidisciplinary Analysis campaign). J. Geophys. Res. Atmospheres 113. https://doi.org/10.1029/2008JD009904

Fernández-Camacho, R., Rodríguez, S., De, L.R., Sánchez, D.L.C., Viana, M., Alastuey, A., Querol, X., 2010. Ultrafine particle formation in the inland sea breeze airflow in Southwest Europe. Atmospheric Chem. Phys. 10, 9615-9630. https://doi.org/10.5194/acp-109615-2010

Flament, P., Deboudt, K., Cachier, H., Châtenet, B., Mériaux, X., 2011. Mineral dust and carbonaceous aerosols in West Africa: Source assessment and characterization. Atmos. Environ. 45, 3742-3749. https://doi.org/10.1016/j.atmosenv.2011.04.013

Gao, J., Xue, M., Shapiro, A., Droegemeier, K.K., 1999. A Variational Method for the Analysis of Three-Dimensional Wind Fields from Two Doppler Radars. Mon. Weather Rev. 127, 2128-2142. https://doi.org/10.1175/1520-0493(1999)127<2128:AVMFTA>2.0.CO;2

Ge, J.M., Liu, H., Huang, J., Fu, Q., 2016. Taklimakan Desert nocturnal low-level jet: climatology and dust activity. Atmos Chem Phys 16, 7773-7783. https://doi.org/10.5194/acp16-7773-2016

Hand, J.L., Malm, W.C., 2007. Review of aerosol mass scattering efficiencies from ground-based measurements since 1990. J. Geophys. Res. Atmospheres 112, D16203. https://doi.org/10.1029/2007JD008484

Hidalgo, H.G., Durán-Quesada, A.M., Amador, J.A., Alfaro, E.J., 2015. The Caribbean Low-Level Jet, the Inter-Tropical Convergence Zone and Precipitation Patterns in the IntraAmericas Sea: A Proposed Dynamical Mechanism. Geogr. Ann. Ser. Phys. Geogr. 97, 41-59. https://doi.org/10.1111/geoa.12085

Huneeus, N., Schulz, M., Balkanski, Y., Griesfeller, J., Prospero, J., Kinne, S., Bauer, S., Boucher, O., Chin, M., Dentener, F., Diehl, T., Easter, R., Fillmore, D., Ghan, S., Ginoux, P., Grini, A., Horowitz, L., Koch, D., Krol, M.C., Landing, W., Liu, X., Mahowald, N., 
Miller, R., Morcrette, J.-J., Myhre, G., Penner, J., Perlwitz, J., Stier, P., Takemura, T., Zender, C.S., 2011. Global dust model intercomparison in AeroCom phase I. Atmospheric Chem. Phys. 11, 7781-7816. https://doi.org/10.5194/acp-11-7781-2011

Iwai, H., Murayama, Y., Ishii, S., Mizutani, K., Ohno, Y., Hashiguchi, T., 2011. Strong Updraft at a Sea-Breeze Front and Associated Vertical Transport of Near-Surface Dense Aerosol Observed by Doppler Lidar and Ceilometer. Bound.-Layer Meteorol. 141, 117. https://doi.org/10.1007/s10546-011-9635-z

Kaly, F., Marticorena, B., Chatenet, B., Rajot, J.-L., Janicot, S., Niang, A., Yahi, H., Thiria, S., Maman, A., Zakou, A., Coulibaly, B.S., Coulibaly, M., Kone, I., Traore, S., Diallo, 10 A., Ndiaye, T., 2015. Variability of mineral dust concentrations over West Africa monitored by the Sahelian Dust Transect. Atmospheric Res. 164, 226-241. https://doi.org/10.1016/j.atmosres.2015.05.011

Karyampudi, V.M., Palm, S.P., Reagen, J.A., Fang, H., Grant, W.B., Hoff, R.M., Moulin, C., Pierce, H.F., Torres, O., Browell, E.V., Melfi, S.H., 1999. Validation of the 15 Saharan Dust Plume Conceptual Model Using Lidar, Meteosat, and ECMWF Data. Bull. Am. Meteorol. Soc. $\quad$ S0, 1045-1075. https://doi.org/10.1175/15200477(1999)080<1045:VOTSDP>2.0.CO;2

Kim, E.H., Suh, K.S., Hwang, W.T., Jeong, H.J., Han, M.H., Moon, J.Y., 2007. Analysis of the site characteristics of Korean nuclear power sites from the meteorological aspects. Ann. Nucl. Energy Oxf. 34, 719-723. https://doi.org/10.1016/j.anucene.2007.03.006

Kolev, I., Parvanov, O., Kaprielov, B., Donev, E., Ivanov, D., 1998. Lidar Observations of Sea-Breeze and Land-Breeze Aerosol Structure on the Black Sea. J. Appl. Meteorol. 37, 982-995. https://doi.org/10.1175/1520-0450(1998)037<0982:LOOSBA>2.0.CO;2

Kulmala, M., Arola, A., Nieminen, T., Riuttanen, L., Sogacheva, L., De, L., Lehtinen, K.E.J., 2011. The first estimates of global nucleation mode aerosol concentrations based on satellite measurements. Atmospheric Chem. Phys. 11, 10791-10801. https://doi.org/10.5194/acp-11-10791-2011

Kumer, V.-M., Reuder, J., Furevik, B.R., 2014. A Comparison of LiDAR and Radiosonde Wind Measurements. Energy Procedia, EERA DeepWind' 2014, 11th Deep Sea Offshore Wind R\&D Conference 53, 214-220. https://doi.org/10.1016/j.egypro.2014.07.230

Lee, T., Choi, J., Lee, G., Ahn, J., Park, J.S., Atwood, S.A., Schurman, M., Choi, Y., 
Chung, Y., Collett, J.L., 2015. Characterization of aerosol composition, concentrations, and sources at Baengnyeong Island, Korea using an aerosol mass spectrometer. Atmos. Environ. 120, 297-306. https://doi.org/10.1016/j.atmosenv.2015.08.038

Lee, Y.-G., Lee, H.-W., Kim, M.-S., Choi, C.Y., Kim, J., 2008. Characteristics of particle formation events in the coastal region of Korea in 2005. Atmos. Environ. 42, 37293739. https://doi.org/10.1016/j.atmosenv.2007.12.064

Léon, J.F., Derimian, Y., Chiapello, I., Tanré, D., Podvin, T., Chatenet, B., Diallo, A., Deroo, C., 2009. Aerosol vertical distribution and optical properties over M'Bour (16.96 degrees W; 14.39 degrees N), Senegal from 2006 to 2008. Atmospheric Chem. Phys. 9, 9249-9261.

Leroux, M., 2001. The meteorology and climate of tropical Africa. Springer Science \& Business Media.

Levy, I., Mahrer, Y., Dayan, U., 2009. Coastal and synoptic recirculation affecting air pollutants dispersion: A numerical study. Atmos. Environ. 43, 1991-1999. https://doi.org/10.1016/j.atmosenv.2009.01.017

Luhar, A.K., Sawford, B.L., Hacker, J.M., Rayner, K.N., 1998. The Kwinana Coastal Fumigation Study: II - Growth of the Thermal Internal Boundary Layer. Bound.-Layer Meteorol. 89, 385-405. https://doi.org/10.1023/A:1001746303967

Madougou, S., Saïd, F., Campistron, B., Lothon, M., Kebe, C.F., 2012. Results of UHF radar observation of the nocturnal low-level jet for wind energy applications. Acta Geophys. 60, 1413-1453. https://doi.org/10.2478/s11600-012-0062-4

Marengo, J.A., Soares, W.R., Saulo, C., Nicolini, M., 2004. Climatology of the LowLevel Jet East of the Andes as Derived from the NCEP-NCAR Reanalyses: Characteristics and Temporal Variability. J. Clim. 17, 2261-2280. https://doi.org/10.1175/15200442(2004)017<2261:COTLJE>2.0.CO;2

Marticorena, B., Chatenet, B., Rajot, J.L., Traoré, S., Coulibaly, M., Diallo, A., Koné, I., Maman, A., NDiaye, T., Zakou, A., 2010. Temporal variability of mineral dust concentrations over West Africa: analyses of a pluriannual monitoring from the AMMA Sahelian Dust Transect. Atmos Chem Phys 10, 8899-8915. https://doi.org/10.5194/acp-108899-2010

Matsuki, A., Quennehen, B., Schwarzenboeck, A., Crumeyrolle, S., Venzac, H., Laj, P., 
Gomes, L., 2010. Temporal and vertical variations of aerosol physical and chemical properties over West Africa: AMMA aircraft campaign in summer 2006. Atmos Chem Phys 10, 8437-8451. https://doi.org/10.5194/acp-10-8437-2010

Melas, D., Kambezidis, H.D., 1992. The depth of the internal boundary layer over an 5 urban area under sea-breeze conditions. Bound.-Layer Meteorol. 61, 247-264. https://doi.org/10.1007/BF02042934

Middlebrook, A.M., Bahreini, R., Jimenez, J.L., Canagaratna, M.R., 2012. Evaluation of Composition-Dependent Collection Efficiencies for the Aerodyne Aerosol Mass Spectrometer using Field Data. Aerosol Sci. Technol. 46, 258-271. https://doi.org/10.1080/02786826.2011.620041

Miller, S.T.K., Keim, B.D., Talbot, R.W., Mao, H., 2003. Sea breeze: Structure, forecasting, and impacts. Rev. Geophys. 41. https://doi.org/10.1029/2003RG000124

Moorthy, K.K., Murthy, B.V.K., Nair, P.R., 1993. Sea-Breeze Front Effects on Boundary-layer Aerosols at a Tropical Coastal Station. J. Appl. Meteorol. 32, 1196-1205. https://doi.org/10.1175/1520-0450(1993)032<1196:SBFEOB>2.0.CO;2

Mortier, A., Goloub, P., Derimian, Y., Tanré, D., Podvin, T., Blarel, L., Deroo, C., Marticorena, B., Diallo, A., Ndiaye, T., 2016. Climatology of aerosol properties and clear-sky shortwave radiative effects using Lidar and Sun photometer observations in the Dakar site. J. Geophys. Res. Atmospheres 121, 2015JD024588. https://doi.org/10.1002/2015JD024588

Müller, T., Laborde, M., Kassell, G., Wiedensohler, A., 2011. Design and performance of a three-wavelength LED-based total scatter and backscatter integrating nephelometer. Atmos Meas Tech 4, 1291-1303. https://doi.org/10.5194/amt-4-1291-2011

Nankar, D.P., Patra, A.K., Dole, M.U., Venkataraman, S., Hegde, A.G., 2009. Atmospheric stagnation, recirculation and ventilation characteristics at Kakrapar atomic power station site. Ann. Nucl. Energy 36, 475-480. https://doi.org/10.1016/j.anucene.2008.12.005

Nielsen, J.W., 1992. In Situ Observations of Kelvin-Helmholtz Waves along a Frontal Inversion. J. Atmospheric Sci. 49, 369-386. https://doi.org/10.1175/15200469(1992)049<0369:ISOOKH>2.0.CO;2

Paatero, P., Tapper, U., 1994. Positive matrix factorization: A non-negative factor model with optimal utilization of error estimates of data values. Environmetrics 5, 111-126. 
Parker, D.J., Burton, R.R., Diongue-Niang, A., Ellis, R.J., Felton, M., Taylor, C.M., Thorncroft, C.D., Bessemoulin, P., Tompkins, A.M., 2005. The diurnal cycle of the West African monsoon circulation. Q. J. R. Meteorol. Soc. 131, 2839-2860. https://doi.org/10.1256/qj.04.52

Pérez, I.A., Sánchez, M.L., García, M.A., Paredes, V., 2011. Relationship between $\mathrm{CO}(2)$ at a rural site and integral measures of atmospheric stagnation, recirculation, and ventilation. Naturwissenschaften 98, 565-574. https://doi.org/10.1007/s00114-011-0800-5

Pérez, N., Pey, J., Cusack, M., Reche, C., Querol, X., Alastuey, A., Viana, M., 2010. Variability of Particle Number, Black Carbon, and PM10, PM2.5, and PM1 Levels and Speciation: Influence of Road Traffic Emissions on Urban Air Quality. Aerosol Sci. Technol. 44, 487-499. https://doi.org/10.1080/02786821003758286

Pérez, N., Pey, J., Reche, C., Cortés, J., Alastuey, A., Querol, X., 2016. Impact of harbour emissions on ambient PM10 and PM2.5 in Barcelona (Spain): Evidences of secondary aerosol formation within the urban area. Sci. Total Environ. 571, 237-250. https://doi.org/10.1016/j.scitotenv.2016.07.025

Physick, W.L., Abbs, D.J., 1992. Flow and Plume Dispersion in a Coastal Valley. J. Appl. Meteorol. 31, 64-73. https://doi.org/10.1175/15200450(1992)031<0064:FAPDIA>2.0.CO;2

Piazzola, J., Sellegri, K., Bourcier, L., Mallet, M., Tedeschi, G., Missamou, T., 2012. Physicochemical characteristics of aerosols measured in the spring time in the Mediterranean coastal zone. Atmos. Environ. 54, 545-556. https://doi.org/10.1016/j.atmosenv.2012.02.057

Pichugina, Y.L., Brewer, W.A., Banta, R.M., Choukulkar, A., Clack, C.T.M., Marquis, M.C., McCarty, B.J., Weickmann, A.M., Sandberg, S.P., Marchbanks, R.D., Hardesty, R.M., 2017. Properties of the offshore low level jet and rotor layer wind shear as measured by scanning Doppler Lidar. Wind Energy 20, 987-1002. https://doi.org/10.1002/we.2075

Rivellini, L.-H., Chiapello, I., Tison, E., Fourmentin, M., Féron, A., Diallo, A., N'Diaye, T., Goloub, P., Canonaco, F., Prévôt, A.S.H., Riffault, V., 2017. Chemical characterization and source apportionment of submicron aerosols measured in Senegal during the 2015 SHADOW campaign. Atmos Chem Phys 17, 10291-10314. https://doi.org/10.5194/acp-17-10291-2017

Rodríguez, S., Cuevas, E., González, Y., Ramos, R., Romero, P.M., Pérez, N., Querol, 
X., Alastuey, A., 2008. Influence of sea breeze circulation and road traffic emissions on the relationship between particle number, black carbon, PM1, PM2.5 and PM2.5-10 concentrations in a coastal city. Atmos. Environ. 42, 6523-6534. https://doi.org/10.1016/j.atmosenv.2008.04.022

Ruchith, R.D., Ernest Raj, P., 2015. Features of nocturnal low level jet (NLLJ) observed over a tropical Indian station using high resolution Doppler wind lidar. J. Atmospheric Sol.Terr. Phys. 123, 113-123. https://doi.org/10.1016/j.jastp.2015.01.001

Russo, A., Gouveia, C., Levy, I., Dayan, U., Jerez, S., Mendes, M., Trigo, R., 2016. Coastal recirculation potential affecting air pollutants in Portugal: The role of circulation weather types. Atmos. Environ. 135, 9-19. https://doi.org/10.1016/j.atmosenv.2016.03.039

Shapiro, A., Robinson, P., Wurman, J., Gao, J., 2003. Single-Doppler Velocity Retrieval with Rapid-Scan Radar Data. J. Atmospheric Ocean. Technol. 20, 1758-1775. https://doi.org/10.1175/1520-0426(2003)020<1758:SVRWRR>2.0.CO;2

Simpson, J.E., 1969. A comparison between laboratory and atmospheric density currents. Q. J. R. Meteorol. Soc. 95, 758-765. https://doi.org/10.1002/qj.49709540609

Sullivan, J.T., Rabenhorst, S.D., Dreessen, J., McGee, T.J., Delgado, R., Twigg, L., Sumnicht, G., 2017. Lidar observations revealing transport of O3 in the presence of a nocturnal low-level jet: Regional implications for "next-day" pollution. Atmos. Environ. 158, 160-171. https://doi.org/10.1016/j.atmosenv.2017.03.039

Surkova, G., 2013. Air recirculation and ventilation in the coastal regions of the Black Sea. Open Geosci. 5, 196-207. https://doi.org/10.2478/s13533-012-0126-7

Talbot, R.W., Harriss, R.C., Browell, E.V., Gregory, G.L., Sebacher, D.I., Beck, S.M., 1986. Distribution and geochemistry of aerosols in the tropical north Atlantic troposphere: Relationship to Saharan dust. J. Geophys. Res. Atmospheres 91, 5173-5182. https://doi.org/10.1029/JD091iD04p05173

Taubman, B.F., Marufu, L.T., Piety, C.A., Doddridge, B.G., Stehr, J.W., Dickerson, R.R., 2004. Airborne Characterization of the Chemical, Optical, and Meteorological Properties, and Origins of a Combined Ozone-Haze Episode over the Eastern United States. J. Atmospheric Sci. 61, 1781-1793. https://doi.org/10.1175/15200469(2004)061<1781:ACOTCO>2.0.CO;2

Venegas, L.E., Mazzeo, N.A., 1999. Atmospheric stagnation, recirculation and 
ventilation potential of several sites in Argentina. Atmospheric Res. 52, 43-57. https://doi.org/10.1016/S0169-8095(99)00030-7

Verma, S., B, P., Pani, S.K., Bharath, K., Faruqi, A.R., Bhanja, S.N., Mandal, M., 2016. Aerosol extinction properties over coastal West Bengal Gangetic plain under inter-seasonal and sea breeze influenced transport processes. Atmospheric Res. 167, 224-236. https://doi.org/10.1016/j.atmosres.2015.07.021

Veselovskii, I., Goloub, P., Podvin, T., Bovchaliuk, V., Derimian, Y., Augustin, P., Fourmentin, M., Tanre, D., Korenskiy, M., Whiteman, D.N., Diallo, A., Ndiaye, T., Kolgotin, A., Dubovik, O., 2016. Retrieval of optical and physical properties of African dust from 10 multiwavelength Raman lidar measurements during the SHADOW campaign in Senegal. Atmos Chem Phys 16, 7013-7028. https://doi.org/10.5194/acp-16-7013-2016

Winker, D.M., Hunt, W.H., McGill, M.J., 2007. Initial performance assessment of CALIOP. Geophys. Res. Lett. 34, L19803. https://doi.org/10.1029/2007GL030135

Xu, W., Han, T., Du, W., Wang, Q., Chen, C., Zhao, J., Zhang, Y., Li, J., Fu, P., Wang, Z., Worsnop, D.R., Sun, Y., 2017. Effects of Aqueous-Phase and Photochemical Processing on Secondary Organic Aerosol Formation and Evolution in Beijing, China. Environ. Sci. Technol. 51, 762-770. https://doi.org/10.1021/acs.est.6b04498 


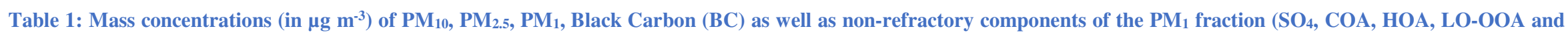
MO-OOA) measured at Mbour on March 28 and March 31 during 5 periods: Morning peak, before SB, SB establishment, SB, and LLJ effect.

\begin{tabular}{|c|c|c|c|c|c|c|c|c|c|}
\hline & $\mathrm{PM}_{10}$ & $\mathrm{PM}_{2.5}$ & $\mathrm{PM}_{1}$ & $\mathrm{BC}$ & $\mathrm{SO}_{4}$ & $\mathrm{COA}$ & $\mathrm{HOA}$ & LO-OOA & MO-OOA \\
\hline & \multicolumn{9}{|c|}{ March 28, 2015} \\
\hline Morning peak & $155.5 \pm 39.9$ & $66.6 \pm 15.1$ & $24.9 \pm 5.2$ & NA & $0.56 \pm 0.04$ & $1.92 \pm 0.39$ & $3.15 \pm 1.58$ & $1.65 \pm 0.74$ & $0.75 \pm 0.16$ \\
\hline Before SB & $67.1 \pm 9.4$ & $25.5 \pm 3.1$ & $7.95 \pm 0.50$ & $0.29 \pm 0.16$ & $0.29 \pm 0.16$ & $0.22 \pm 0.12$ & $0.12 \pm 0.09$ & $0.13 \pm 0.04$ & $0.27 \pm 0.12$ \\
\hline SB Establishment & $59.4 \pm 6.2$ & $37.6 \pm 3.2$ & $23.1 \pm 2.5$ & $0.70 \pm 0.25$ & $2.80 \pm 0.90$ & $1.14 \pm 0.60$ & $1.32 \pm 0.25$ & $1.44 \pm 0.48$ & $2.73 \pm 0.82$ \\
\hline SB & $52.5 \pm 6.6$ & $32.3 \pm 3.5$ & $18.4 \pm 2.9$ & $0.75 \pm 0.16$ & $2.32 \pm 0.27$ & $1.34 \pm 0.37$ & $1.41 \pm 0.41$ & $1.11 \pm 0.37$ & $1.98 \pm 0.51$ \\
\hline \multirow[t]{2}{*}{ LLJ effect } & $82.7 \pm 33.3$ & $34.1 \pm 8.9$ & $12.5 \pm 1.7$ & $0.61 \pm 0.23$ & $0.99 \pm 0.09$ & $0.65 \pm 0.26$ & $0.94 \pm 0.40$ & $0.39 \pm 0.10$ & $0.55 \pm 0.13$ \\
\hline & \multicolumn{9}{|c|}{ March 31, 2015} \\
\hline Morning peak & $331.1 \pm 23.3$ & $138.6 \pm 9.7$ & $41.8 \pm 6.8$ & NA & $0.20 \pm 0.13$ & $2.65 \pm 1.17$ & $5.07 \pm 1.73$ & $2.80 \pm 0.76$ & $1.18 \pm 0.16$ \\
\hline Before SB & $174.7 \pm 37.4$ & $75.6 \pm 11.5$ & $23.9 \pm 4.2$ & $0.14 \pm 0.04$ & $0.24 \pm 0.10$ & $0.18 \pm 0.17$ & $0.19 \pm 0.07$ & $0.20 \pm 0.09$ & $0.39 \pm 0.16$ \\
\hline SB establishment & $118.8 \pm 16.7$ & $67.2 \pm 10.4$ & $20.5 \pm 3.4$ & $0.12 \pm 0.07$ & $0.26 \pm 0.13$ & $0.19 \pm 0.04$ & $0.18 \pm 0.14$ & $0.26 \pm 0.12$ & $0.39 \pm 0.11$ \\
\hline SB & $182.6 \pm 18.3$ & $95.4 \pm 4.3$ & $32.5 \pm 0.9$ & $0.83 \pm 0.18$ & $0.79 \pm 0.18$ & $1.57 \pm 0.79$ & $1.29 \pm 0.08$ & $1.47 \pm 0.24$ & $1.87 \pm 0.31$ \\
\hline LLJ effect & $228.3 \pm 17.9$ & $102.8 \pm 5.0$ & $29.9 \pm 1.9$ & $0.35 \pm 0.03$ & $0.29 \pm 0.05$ & $0.88 \pm 0.22$ & $0.68 \pm 0.27$ & $0.48 \pm 0.11$ & $0.40 \pm 0.16$ \\
\hline
\end{tabular}




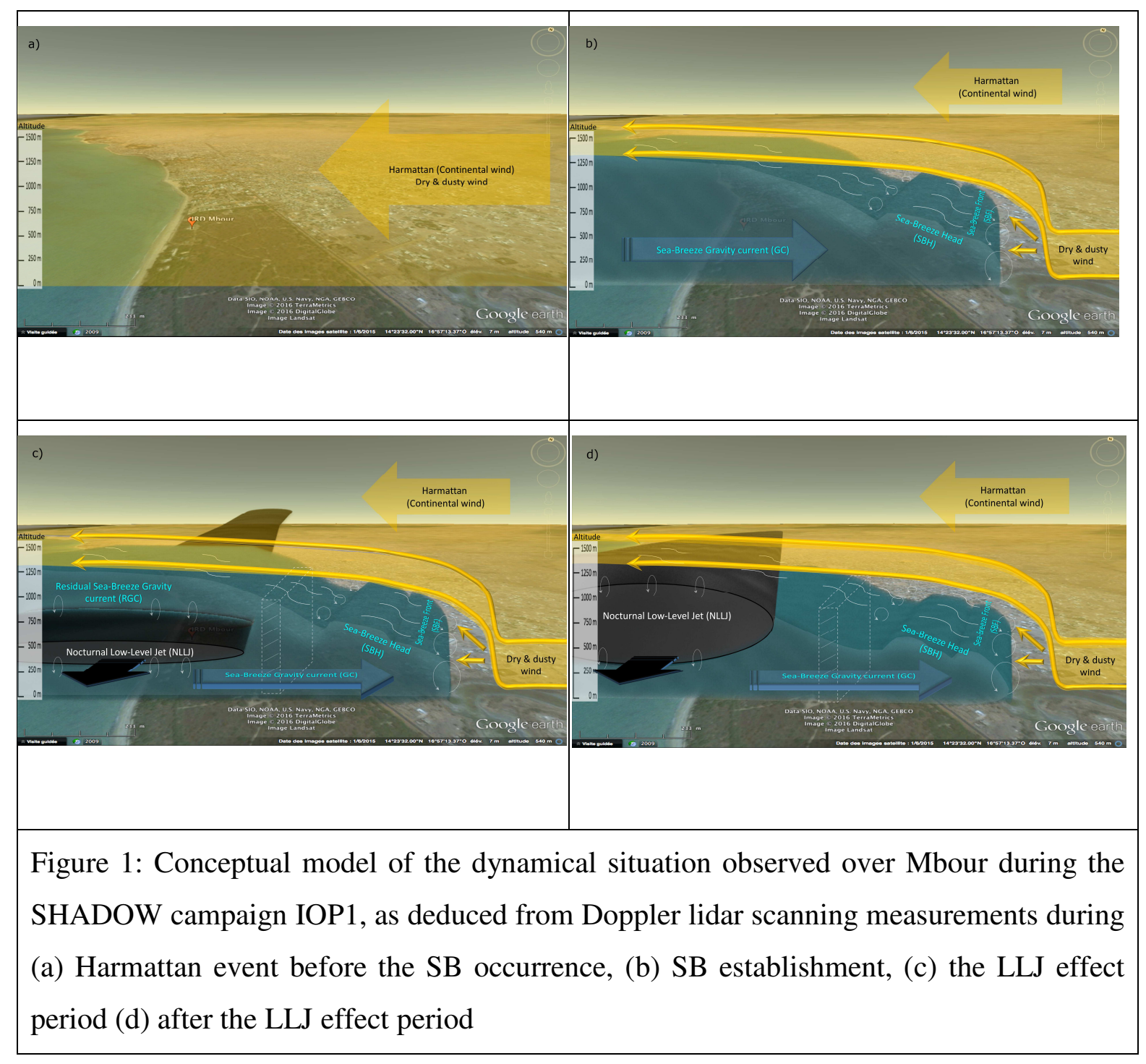




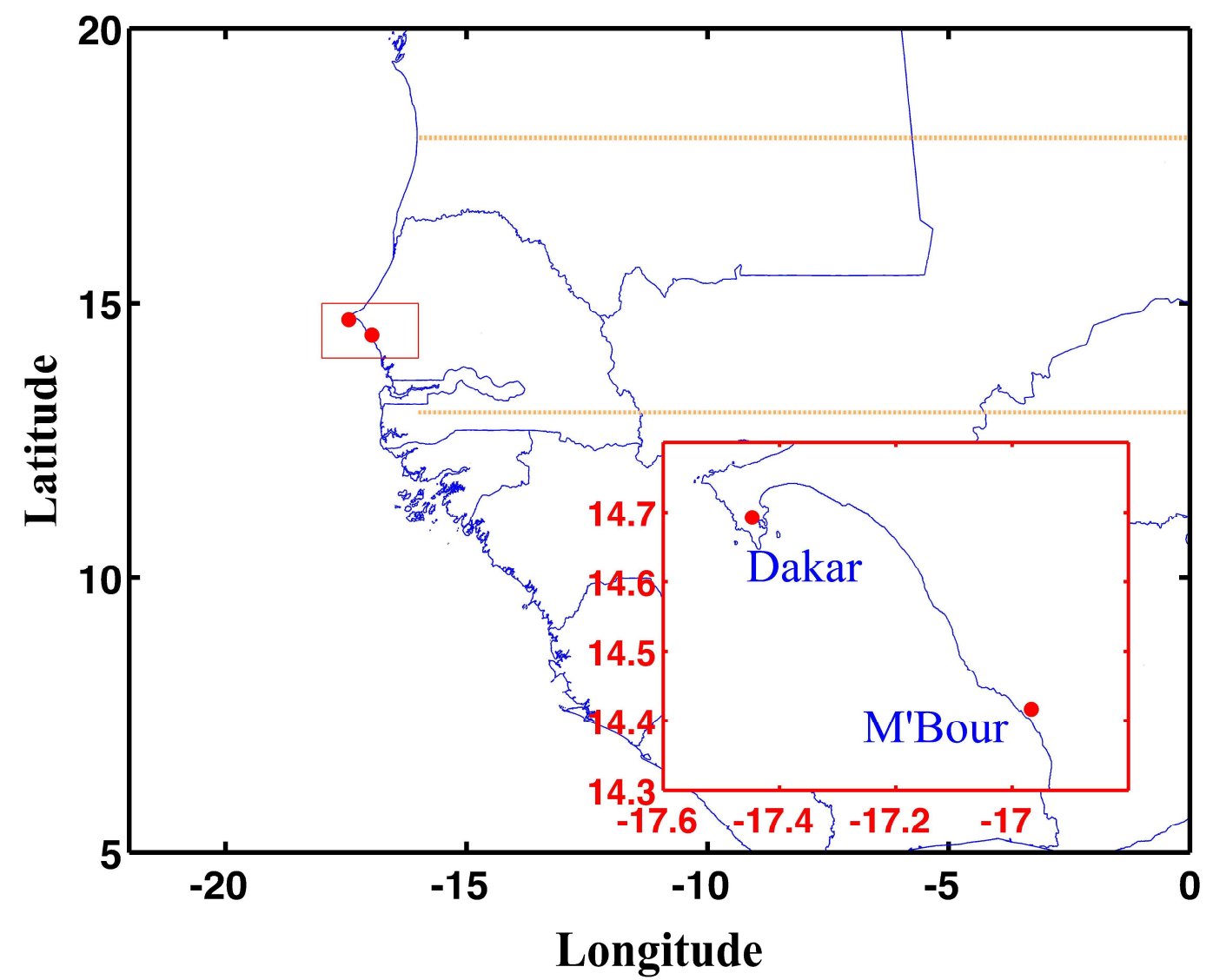

Figure 2: Dakar and Mbour locations. The Sahelian band is represented with the orange square. Note that the site of measurements is located in the Mbour area directly on the Atlantic coast. 


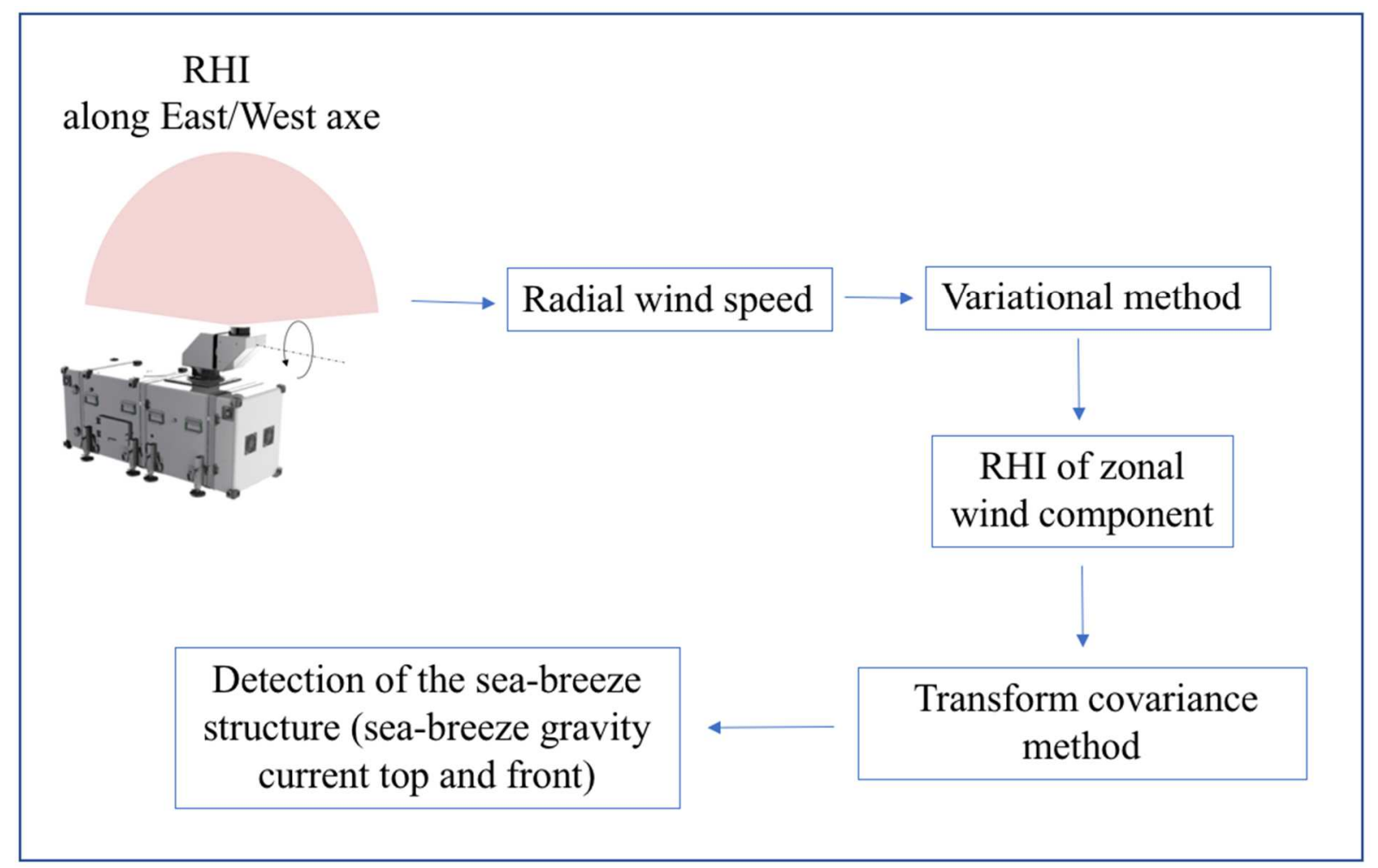

Figure 3: Diagram of the method to deduce the sea-breeze structure from RHI lidar measurements 

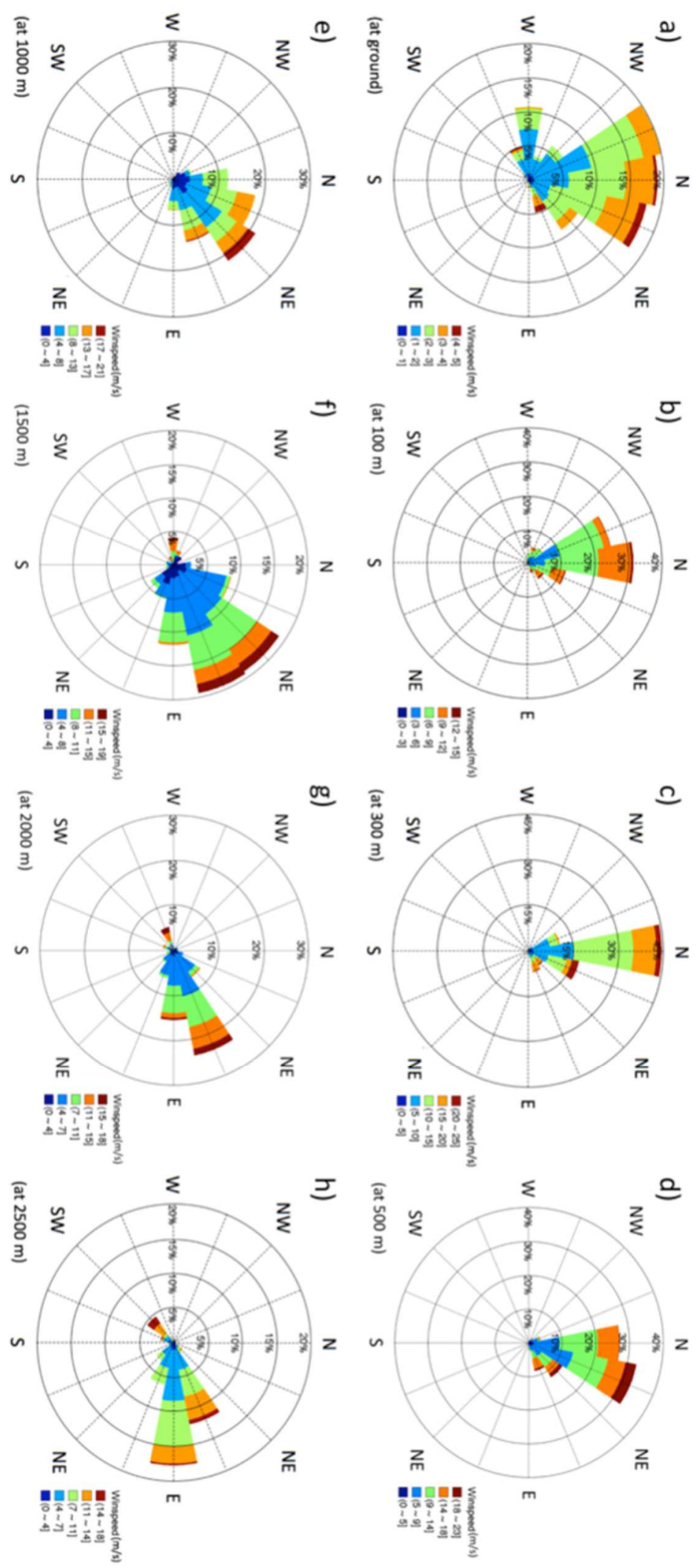

Figure 4: Wind rose plots of the relative frequencies of wind direction (\%) for 8 altitudes: a) at ground level, b) at $100 \mathrm{~m}$ c) $300 \mathrm{~m}$, d) $500 \mathrm{~m}$, e) $1000 \mathrm{~m}$, f) $1500 \mathrm{~m}$, g) $2000 \mathrm{~m}$ and h) at $2500 \mathrm{~m}$. The color scale corresponds to the wind speed. 

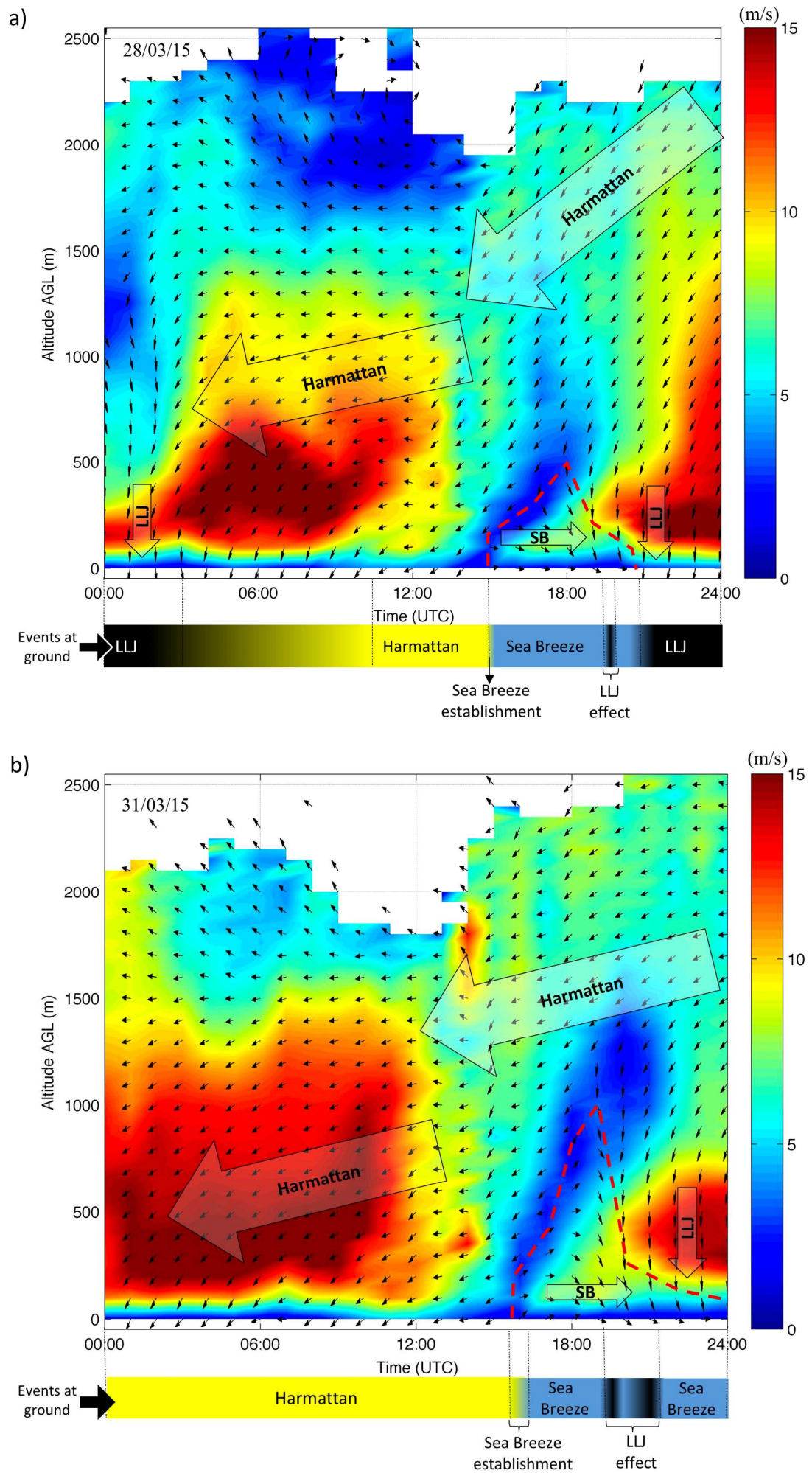

Figure 5: Time-height cross-section of the horizontal wind direction (arrows) and speed (color scale) at Mbour Senegal (a) on 28 March and (b) on 31 March. Downward and leftward arrows represent, northerly wind and easterly wind, respectively. The main flows are mentioned on the graph (SB: sea breeze; LLJ; Low-level jet; GC: gravity current); the SB GC edge is symbolized by a red dashed line and the event periods observed at ground level are mentioned on the bottom strip. 

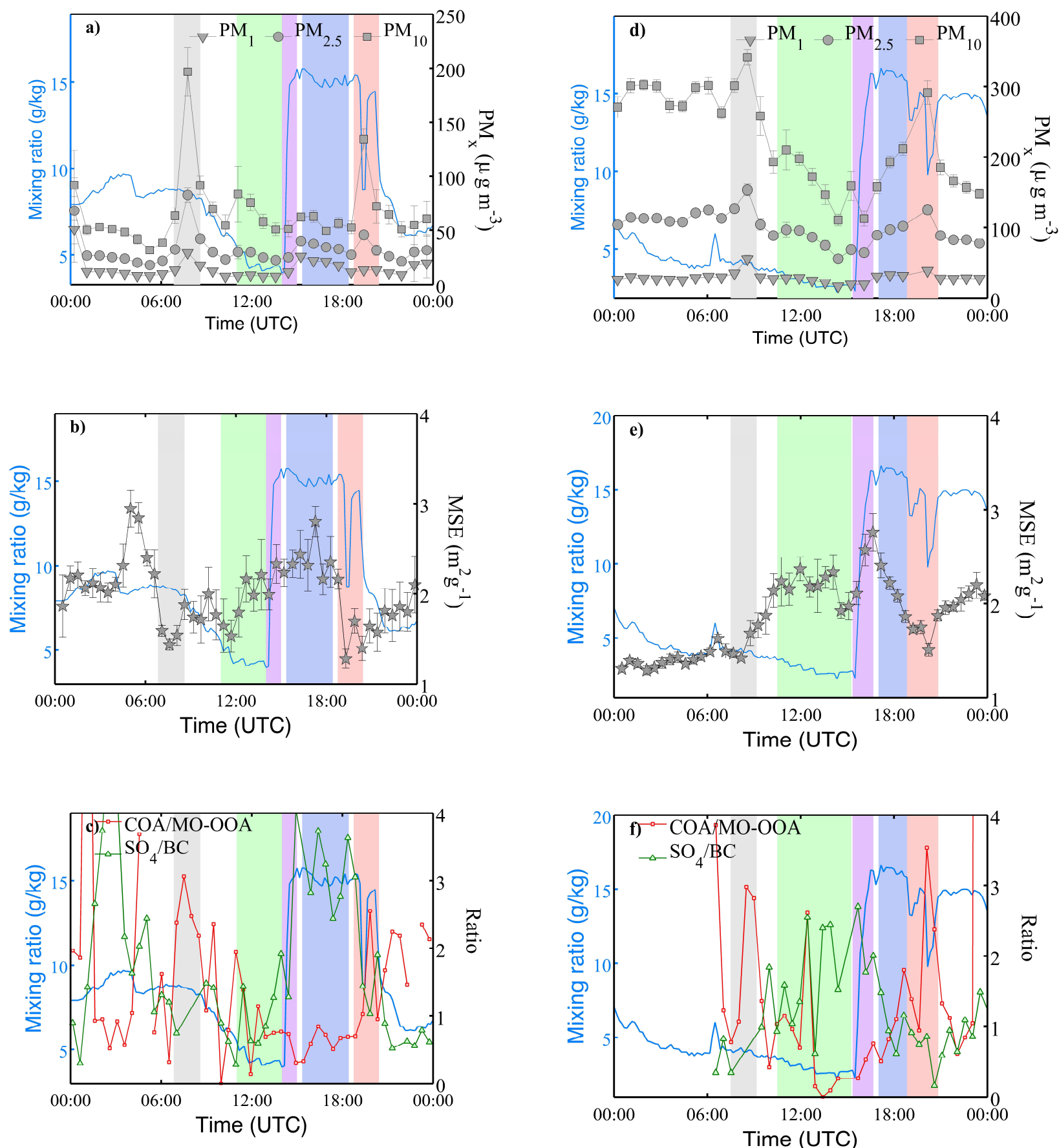

Figure 6: Temporal evolution of the water vapour mixing ratio on 28 March 2015 (left) and 31 March 2015 (right) plotted in parallel of (a and d) the different fraction of particle matter (PM10, PM2.5 and PM1) over Mbour, (b and e) the total mass scattering efficiency (MSE) calculated from the scattering coefficient measured at $525 \mathrm{~nm}$ and the $\mathbf{P M}_{10}$ concentrations over Mbour and (c and f) the COA (Cooking-like Organic Aerosol) to MO-OOA (More-Oxidized Oxygenated Organic Aerosol) ratio (red) and sulfate $\left(\mathrm{SO}_{4}\right)$ to black carbon $(\mathrm{BC})$ ratio (green) observed at Mbour. The shaded areas represent respectively the periods of the morning peak (grey) "Before the SB" (green), the SB establishment (purple), the SB (blue) and the LLJ effect (red), as described in Table 1. A 15 minutes moving average was performed on the raw measurements and only 1 point every 30 minutes was plot corresponding to the ACSM frequency measurement. 

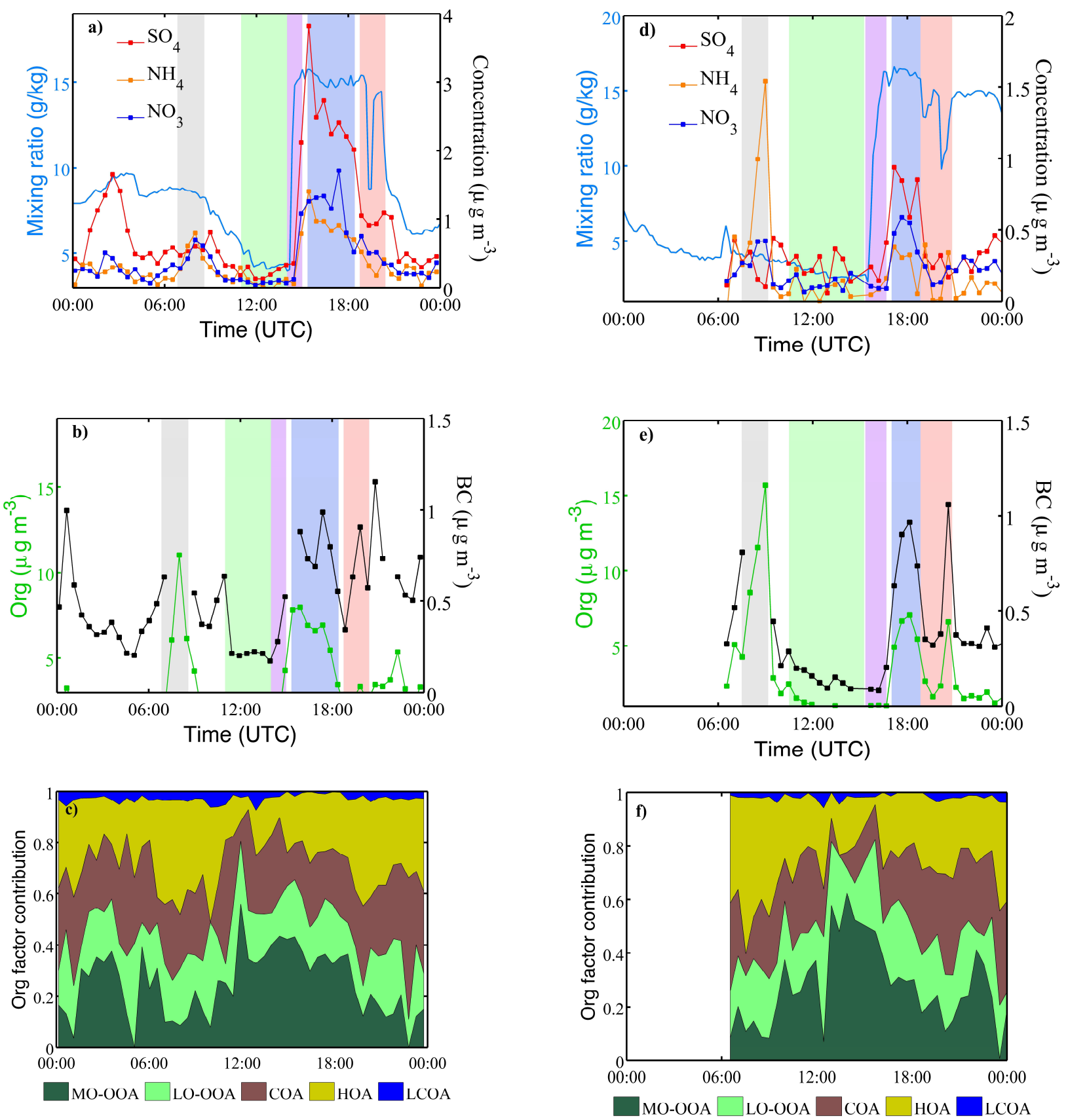

Figure 7: Temporal evolution of the water vapour mixing ratio on 28 March 2015 (left) and 31 March 2015 (right), (a and d) the concentration of $\mathrm{SO}_{4}, \mathrm{NH}_{4}$ and $\mathrm{NO}_{3}$ measured by the ACSM over Mbour, (b and e) the organic factor contribution (MO-OOA, LO-OOA, COA, HOA, LCOA) calculated from Positive Matrix Factorization and (c and f) the Organic and Black Carbon concentration observed at Mbour. The shaded areas represent respectively the periods of the morning peak (grey) "Before the SB" (green), the SB establishment (purple), the SB (blue) and the LLJ effect (red), as described in Table 1. 

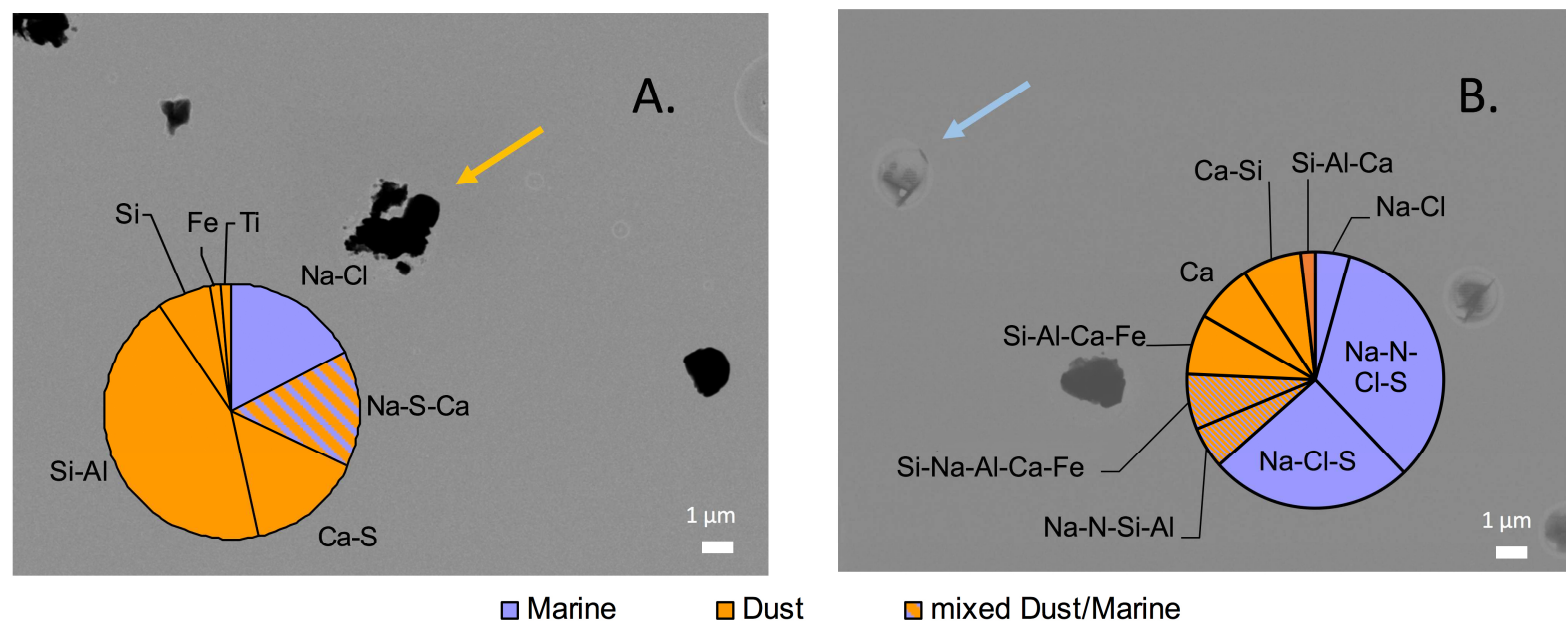

$\square$ mixed Dust/Marine

Figure 8: Typical electron images and elemental composition of dust, marine, mixed dust/marine particles (fraction 1-2.5 $\mu \mathrm{m})$ collected on TEM grid at Mbour on 28 March $2015 \mathrm{~A}$. before (10:50-11:00) and B. during (14:4515:00) during the sea breeze. The composition results from statistical analysis on 213 and 674 particles, respectively. The yellow and blue arrows point to a typical dust or marine particle, respectively. 


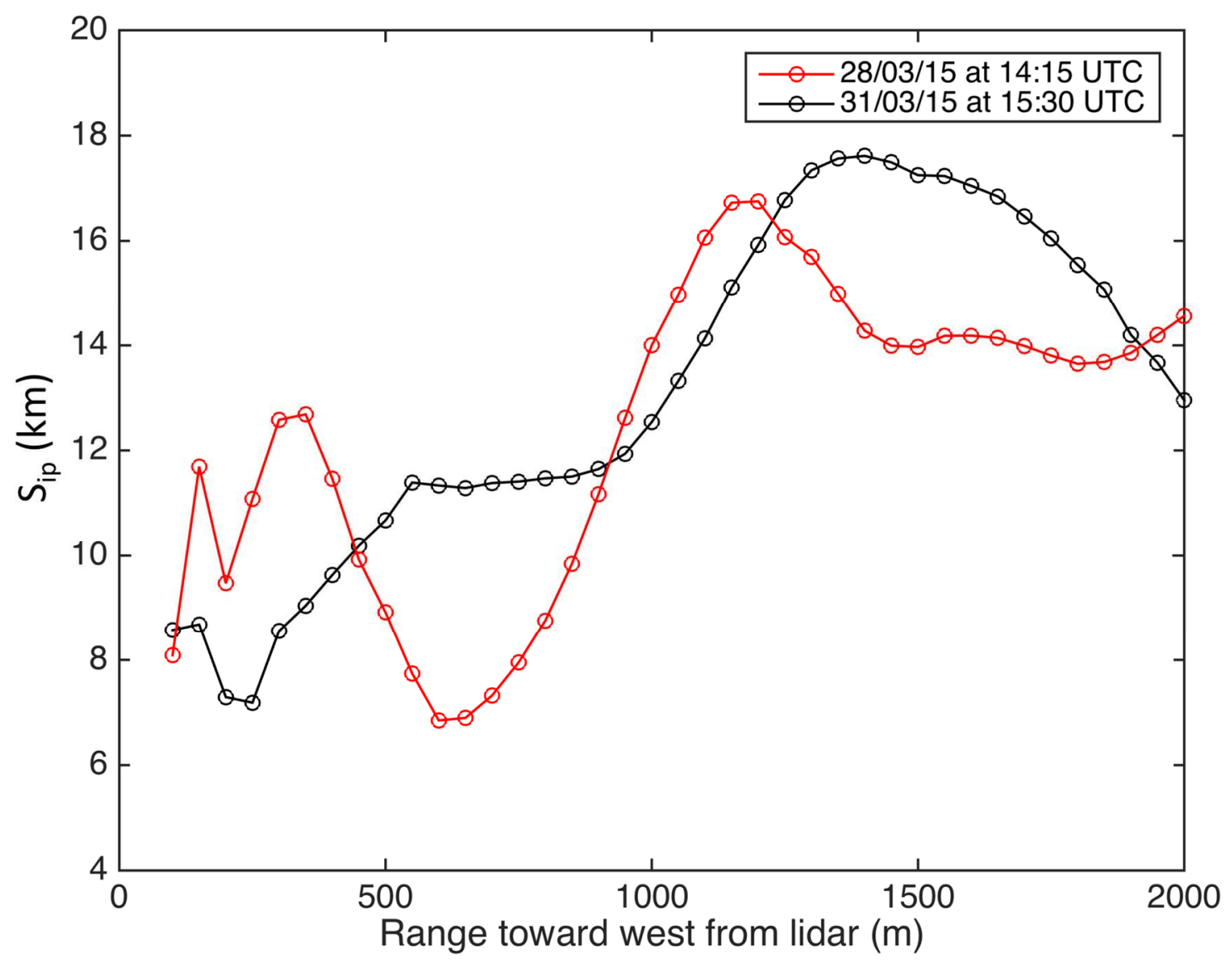

Figure 9: Wind runs $\left(S_{i p}\right)$ time-series computed from the Doppler lidar located at Mbour just before the sea breeze arrival during the 28 March (in red) and during the 31 March (black) for a transport period of 1 hour. 